\title{
Atlante dei borghi solitari: il disegno per le micro-città d'Abruzzo
}

\author{
Giovanni Caffio
}

Abstract

II progetto di rappresentazione presentato in questo articolo, l'Atlante dei borghi solitari, propone un percorso di mappatura architettonica, urbana e territoriale, quale punto di partenza di processi multidisciplinari di conoscenza, atto imprescindibile per poter immaginare e progettare futuri sviluppi economici, ambientali e sociali. II progetto di rappresentazione si svolge attraverso azioni di disegno e ri-disegno, a differenti scale, di micro-città abruzzesi a rischio spopolamento con il fine di aumentare la consapevolezza e la conoscenza condivisa di questi spazi spesso dimenticati. L'opera di mappatura multiscalare può così testimoniare le trasformazioni architettoniche, urbane ed economiche di un territorio che, come le comunità che vi risiedono, è in un lento ma costante stato di trasformazione. Lo studio, inoltre, mostra come i contenuti e gli elaborati presenti nell'Atlante abbiano l'obiettivo ambizioso di costituire una piattaforma flessibile in grado di accogliere nuove e molteplici informazioni e di innescare processi di partecipazione e valorizzazione per le comunità e le amministrazioni locali.

Parole chiave

rappresentazione, piccoli centri, territorio, spopolamento, Abruzzo.

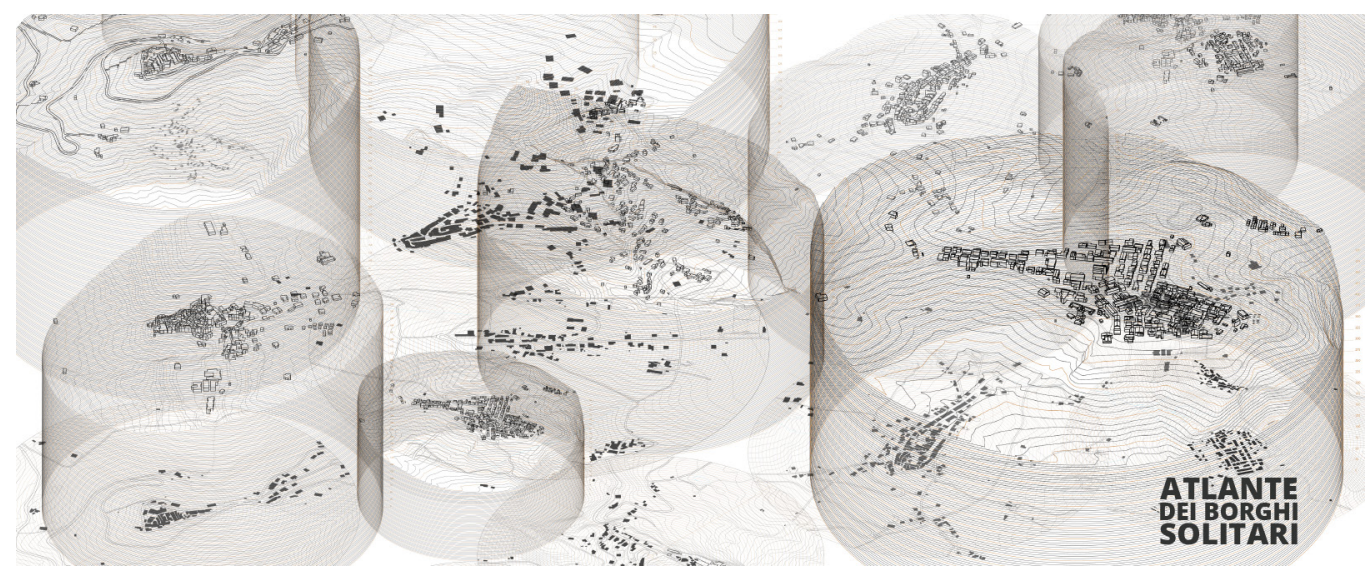




\section{Introduzione}

Da alcuni anni all'interno del Dipartimento di Architettura di Pescara alcuni docenti dell'area della Rappresentazione sono impegnati a studiare i piccoli borghi dell'Abruzzo attraverso opere di mappatura, rilevamento, fotografia e disegno di un ricco patrimonio tangibile e intangibile che, a causa delle dinamiche dello spopolamento, rischia di essere dimenticato e quindi perduto [Caffio 20 I 8; Salucci; Marino 2017; Unali 2020]. II territorio abruzzese, così come in generale quello italiano relativo all'arco alpino e alla dorsale appenninica, è caratterizzato dalla presenza di innumerevoli centri abitati di piccole dimensioni. Questi centri, un tempo asse portante dell'economia locale oggi sempre più fievole traccia della storia passata, stanno perdendo da decenni parti consistenti della propria popolazione secondo un ritmo lento e apparentemente inarrestabile. All'origine di questo spopolamento ci sono molteplici cause endogene ed esogene: catastrofi ambientali succedutesi nel tempo, cambi di paradigma di carattere socioeconomico, nuovi assetti territoriali causati da infrastrutture e insediamenti produttivi. Secondo diversi studiosi [Golini et al. 2000], lo spopolamento, soprattutto in vaste aree pedemontane, montane e insulari, ha ormai assunto una natura strutturale caratterizzando ampie zone in cui il problema del disagio insediativo è solo un effetto di cause eterogenee e sinergiche. Descritto e analizzato nelle sue molteplici implicazioni da studiosi quali Vito Teti [2017; 2004] e Antonella Tarpino [Tarpino 2016; Tarpino 2012], questo processo di sparizione dei centri storici ha provocato, come ulteriore conseguenza, la trasformazione di gran parte della fisionomia dei territori annessi: cancellazione delle forme dell'abitare ma anche mutazione del paesaggio limitrofo. Tale condizione nelle aree dei centri minori risulta poi essere acutizzata dalla assenza di politiche economiche statali rivolte a favorire nuove e più moderne infrastrutture materiali e immateriali. In questo modo, i piccoli centri hanno, di fatto, perso la possibilità di sopravvivere e, nei casi in cui non sono stati ancora del tutto abbandonati, continuano a esistere grazie a una sorta di resistenza caparbia [Polci, Gambassi 2016] (figg. I, 2).
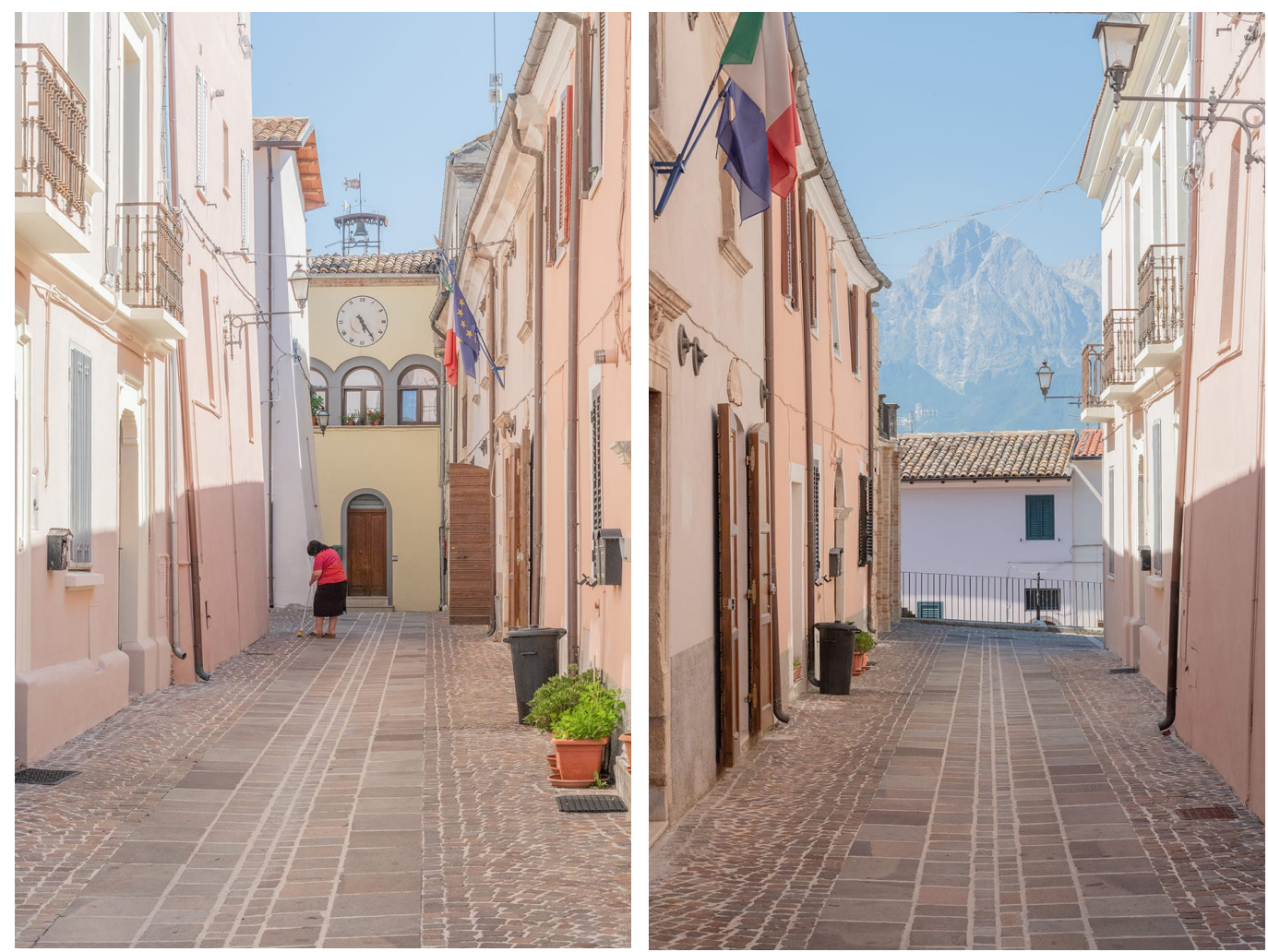


\section{Interni, fragili, marginali... solitari}

Per contrastare questo declino, nel 20 I 4 il governo italiano ha predisposto l'ambizioso piano della Strategia Nazionale delle Aree Interne [SNAI 20 I4], un piano elaborato all'interno dei più ampi programmi di coesione territoriale che ribalta l'approccio basato sullo sviluppo industriale e la predominanza delle grandi metropoli ponendo nuovamente al centro dell'agenda politica i territori considerati marginali. Ė interessante notare come nella SNAI le aree interne siano individuate e classificate a seconda della loro "distanza" dai servizi primari quali istruzione, salute e mobilità, pertanto il loro essere "interne" non è in riferimento al corpo geografico e territoriale quanto al loro essere allontanate dalle possibilità di accedere ai diritti civili contemplati dalla nostra costituzione. Nel caso di questo atlante, invece di usare gli aggettivi 'interno','piccolo','fragile','marginale','negletto' che spesso sono associati a questi borghi nella pubblicistica, abbiamo preferito il meno scontato e prevedibile 'solitario'.

L'aggettivo 'solitario' è stato scelto per i suoi molteplici significati:

a. che sta solo, e soprattutto che ama star solo, che sfugge la compagnia dei propri simili.

b. che è solo, appartato, lontano dagli altri, isolato.

c. di luoghi, deserto, non 'frequentato'.

Ma anche:

"Brillante di notevole pregio, sia per la grandezza sia per il taglio e la luce, incastonato da solo, con una rilegatura leggerissima che lo lasci il più possibile scoperto alla vista, in un anello" [Solitario 202I].

L'idea di questo atlante, pertanto, è quella di ribaltare i preconcetti negativi che formano l'aura di questi centri trasformando in positività le loro peculiarità. Un atteggiamento di valorizzazione e cura dei potenziali presenti in questi luoghi a partire dal loro essere piccoli, e quindi più gestibili; lontani, e quindi più protetti dalle dinamiche imprevedibili della società odierna - vedi pandemia -; vetusti, e quindi più resilienti; poco abitati, e quindi silenziosi e pacifici nonché più vicini alla natura e al paesaggio di cui sono parte integrale (fig. 3).

Fig. 3. Rocca di Cambio (480 abitanti) in provincia di L'Aquila (foto di Giuseppe Marino)

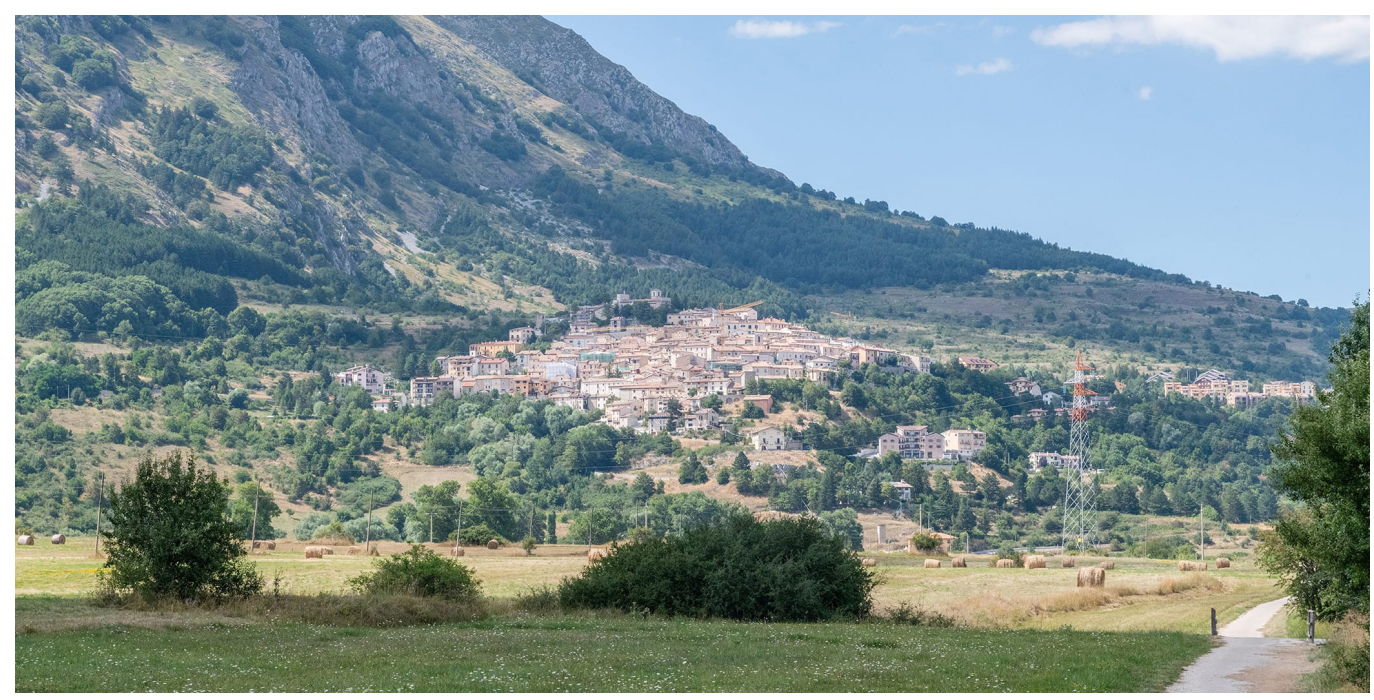

\section{Un obiettivo ambizioso}

Come suggerisce il titolo della ricerca, l'Atlante dei borghi solitari è prima di tutto un progetto di ricerca e rappresentazione di luoghi e spazi dell'abitare in costante sebbene lenta, trasformazione. Pertanto, il suo primo obiettivo è studiare e far emergere le potenzialità dei luoghi abbandonati e innescare un prolifico dialogo tra questi e le energie creative dei visitatori o studiosi dell'atlante (fig. 4). Mostrando le architetture e gli spazi costruiti, e i 
loro valori culturali e sociali di cui sono testimonianza e traccia materica, l'atlante intende quindi favorire una possibile nuova relazione tra vita passata e futura favorendo nuovi usi temporanei e processi di trasformazione che sfuggano all'esclusiva ottica di sfruttamento turistico verso opzioni meno scontate e superficiali in quanto legate alla storia e alla cultura delle comunità locali.

Come scrive Annunziata Maria Oteri, "Come per le persone fragili, che non hanno bisogno di farmaci prodigiosi ma di ascolto, un ruolo importante possono dunque avere le comunità, intese in chiave terapeutica di 'comunità di cura' o, anche di 'comunità di destino', cioè, citando ancora Borgna, delle 'forme di vita, di vicinanza umana e di solidarietà' nelle quali "il più forte dia una mano al più debole'" [Oteri 2019, p. I89]. In questo senso, il progetto di Atlante si pone come punto di ascolto, luogo in cui le comunità locali possano trovare espressione del loro essere, con tutte le idiosincrasie che questo comporti nell'essere distanti se non allontanate dal discorso corrente; uno spazio di confronto e crescita in cui essere riconosciute e rispettate senza incorrere in atteggiamenti salvifici, paternalistici o, al peggio, predatori.

Il fine principale di questo atlante è, infatti, portare l'attenzione su questi centri attraverso la sperimentazione di processi di rappresentazione adattabile, in cui il l'aggettivo è impiegato per sottolineare i diversi significati di questa visione. Innanzi tutto c'è l'idea di una rappresentazione che si adatta alla scala e al contesto senza mai scadere nel pittoresco o nell'effetto cartolina che spesso incornicia le rappresentazioni dei borghi in ambito mainstream; in se-

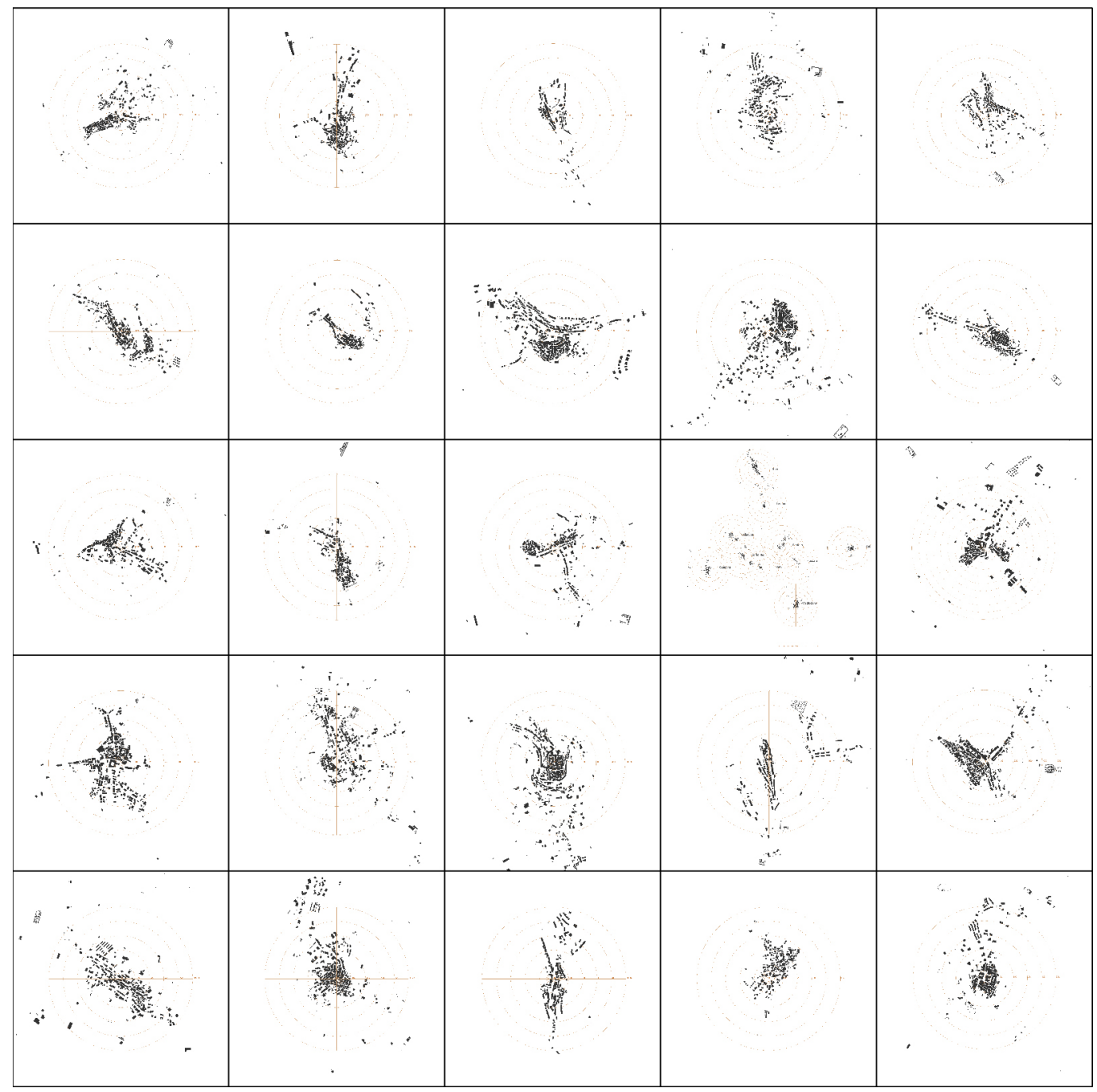


condo luogo si riferisce al fatto che si applica a organismi viventi che si trasformano continuamente e pertanto il disegno deve evidenziare elementi hard intorno ai quali si volgono elementi soft legati ad attività più dinamiche e in evoluzione; infine la rappresentazione deve poter tener conto della componente temporale sperimentando diversi gradi di cambiamento o dinamismo dichiarando che si tratta di disegni sempre in divenire e mai definitivi. Nella rappresentazione, infatti, il disegno del patrimonio architettonico e dell'ambiente costituisce una piattaforma per una visione integrata in cui la rappresentazione fisica dei volumi architettonici si incontra con quella relativa ai processi sociali attraverso indagini statistiche e demografiche che possano combinare anche graficamente la conoscenza e interpretazione del patrimonio fisico urbano con quella delle dinamiche demografiche della popolazione che lo abita e lo usa. Un comune denominatore di queste forme di rappresentazione ibride è la volontà di ricercare nuove combinazioni che favoriscano la costruzione di una nuova narrazione condivisa sulla qualità di questi territori.

Questa narrazione, che oggi associamo il termine di storytelling prendendolo a prestito da altri ambiti linguistici, deve partire dal riconoscimento dell'insieme di risorse del territorio, spesso ignote alla stessa comunità, non come semplice atto identitario ma come nucleo fondante di un processo evolutivo e di crescita. II disegno, quindi, punta operare un'organizzazione delle molteplici informazioni che si ricavano dai luoghi attraverso l'individuazione di elementi dalla forte carica simbolica - monumenti, luoghi specifici, edifici storici, spazi di
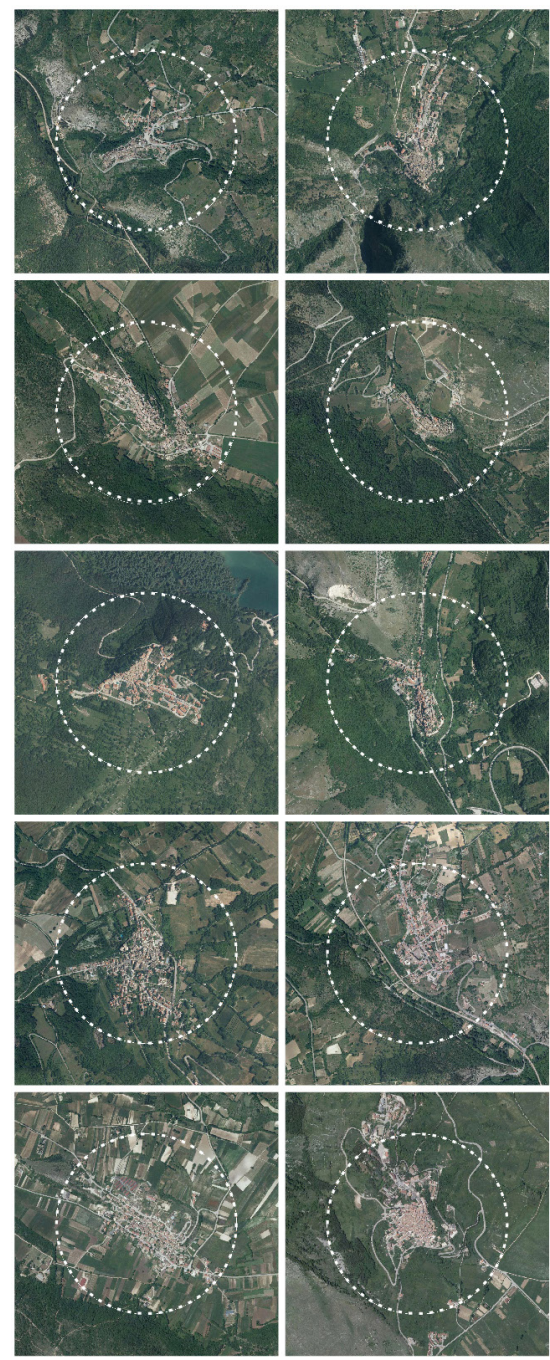
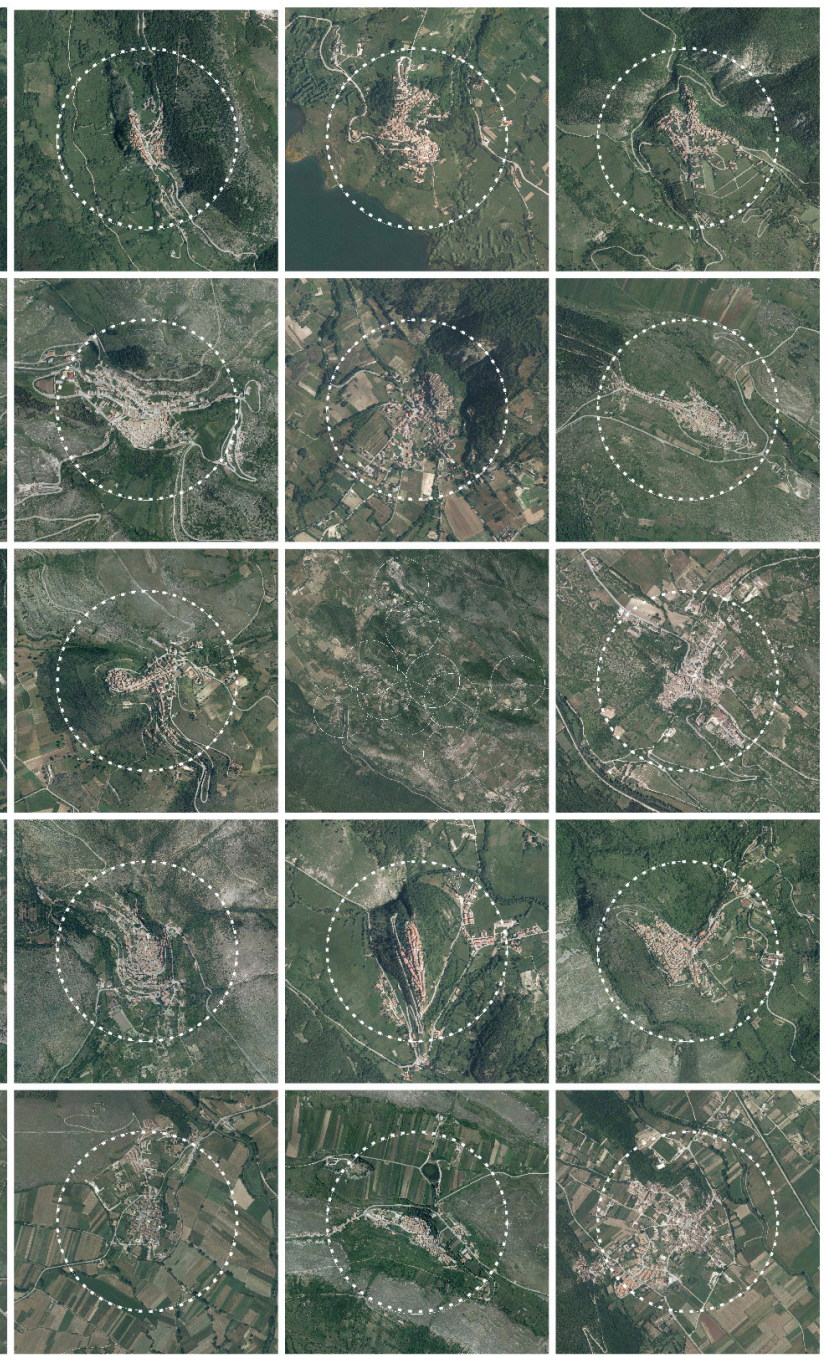
aggregazione - che possano fungere da punti di riferimento nei processi di cambiamento, sorta di "dispositivi di sicurezza" [Oteri 20 19, p. 191] intorno ai quali far riaggregare e attualizzare saperi e culture del passato. Ricercando l'integrazione di rappresentazioni differenti (planimetrie, modelli tridimensionali, diagrammi e grafici statistici, fotografia e disegno a mano) e sperimentando possibili approcci sinergici, questo atlante mira a elaborare descrizioni dei luoghi che siano efficaci, evocative, flessibili e utili (figg. 6-8).

Dopo che tanta attenzione è stata data a forme di rilevamento basate su strumenti e metodiche che, seppur indubbiamente efficaci e insostituibili, allontanano sempre di più l'osservatore dall'oggetto da rappresentare (oggetti concreti e pesanti che si smaterializzano in nuvole di punti, pareti la cui stratigrafia complessa racconta materiali e tecniche sedimentate nel territorio trasformati in superfici mesh; visioni dall'alto di droni volanti che rendono spazi concreti alla stregua di set cinematografici), questo set di rappresentazioni grafiche e visuali (fig. 9) mira a dimostrare che gli obiettivi di un atlante possono essere raggiunti anche attraverso soluzioni ibride che non solo comprendono le tecnologie recenti ma recuperano l'innata capacità del disegnatore di applicare la propria sensibilità alla conoscenza e interpretazione dello spazio attraverso gli strumenti del disegno (a partire dal disegno a mano libera e all'uso razionale e consapevole delle linee) e tornando a occupare lo spazio fisico interagendo con gli abitanti. Un disegnatore che non si limita a guardare dall'alto il borgo o a cogliere gli aspetti visivamente più accattivanti e 'vendibili' ma si fa rappresentante di un'attenzione diretta, partecipe del futuro e della cura dei luoghi. La nostra idea, quindi,

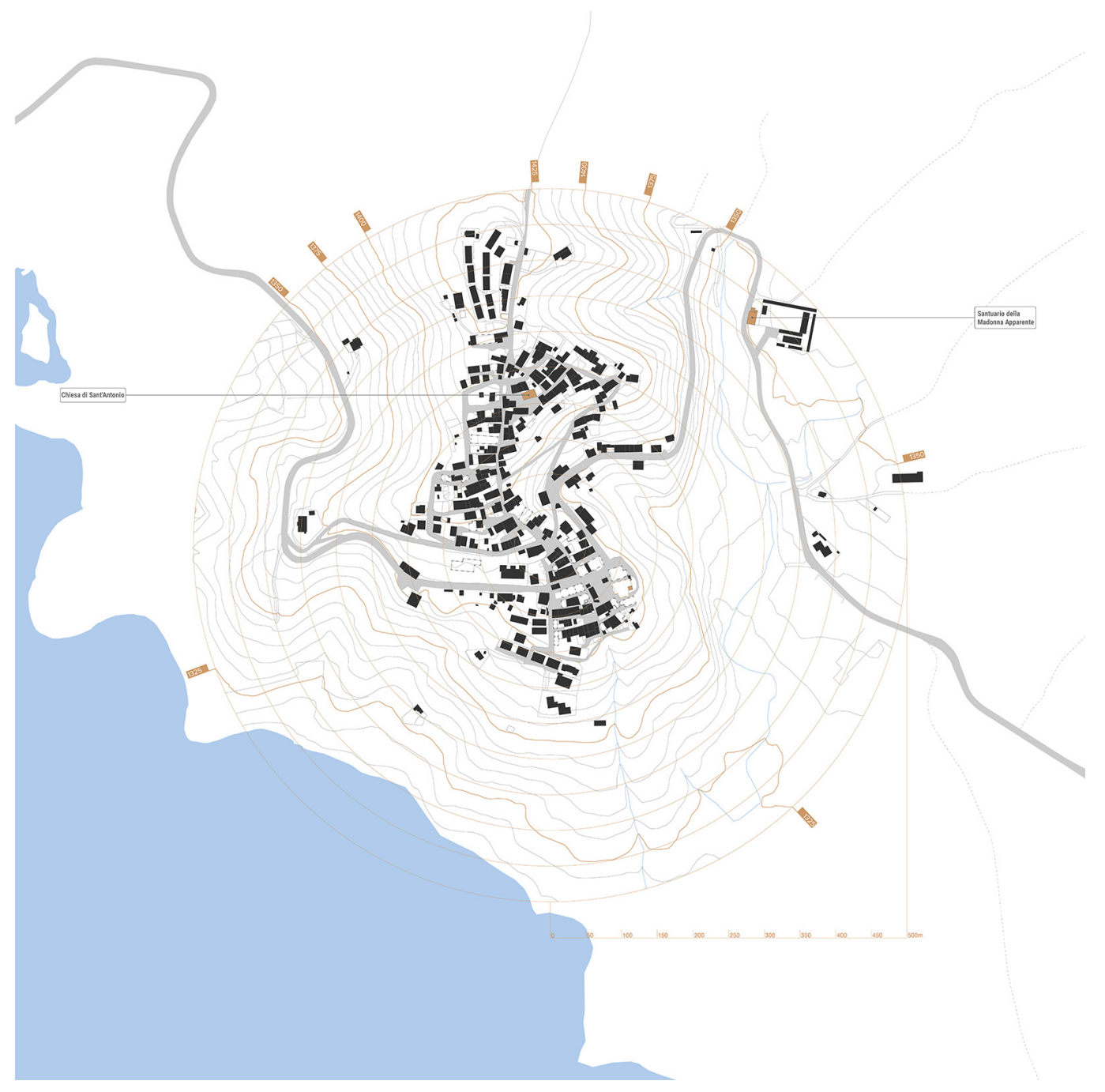


è quella di un disegno come strumento di "ascolto" dei territori fragili, una forma di patto/ legame tra chi viene da fuori e chi è rimasto in questi borghi quasi abbandonati. Alla base del progetto di questo atlante c'è una forma di impegno etico e civico che può essere catalizzatore di nuove opportunità di studio e sviluppo: da progetti di conservazione del patrimonio architettonico e culturale a processi di rigenerazione urbana sostenibile; da una trasformazione degli usi e delle proprietà a strumenti progettuali che stabiliscano nuove relazioni tra architetture, spazi e usi delle comunità residenti.
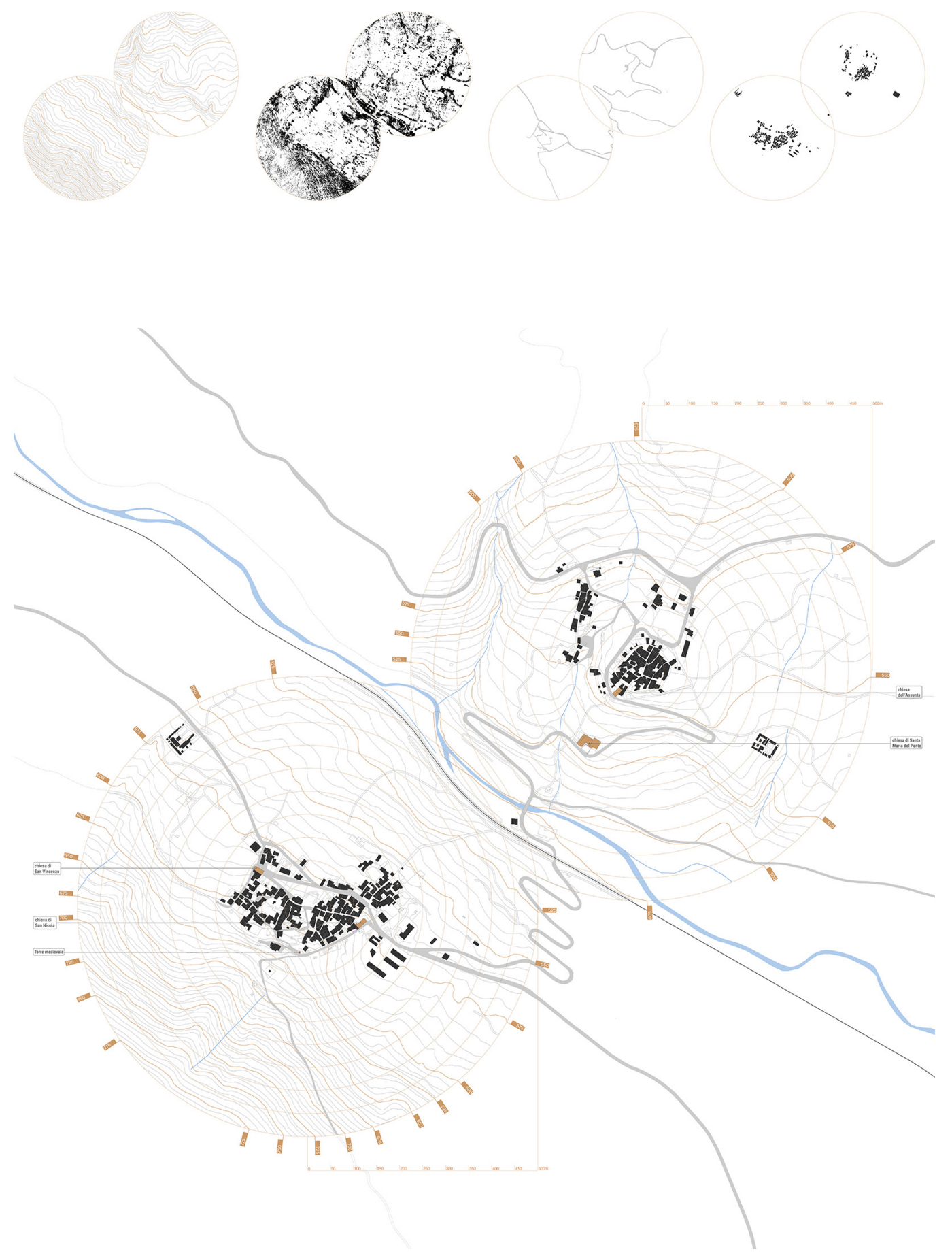


\section{Il perimetro della ricerca}

I disegni qui presentati sono stati l'occasione per indagare il codice semantico e il processo di traduzione che le informazioni possono subire attraverso la rappresentazione. I grafici elaborati sono il risultato di un'esplorazione dei modi attraverso cui il disegno può assumere un nuovo ruolo in relazione ai differenti tipi di dati (geografici, architettonici e demografici) a nostra disposizione, permettendoci così di comprendere, e poi agire, nello spazio intellegibile dell'informazione. Indipendentemente dagli strumenti tecnologici utilizzati - software di modellazione, visualizzazioni in tempo reale di set di dati o semplicemente carta e matita -, questa ricerca punta a esplorare una delle funzioni fondamentali del disegno, owero, comunicare in maniera semplice e diretta dichiarando sempre il suo essere medium e non simulacro. Nell'approcciare questa ricerca ci siamo mossi cercando di perseguire due finalità, ovvero elaborare una descrizione dello stato di fatto dei piccolissimi borghi abruzzesi aggiornata al 2020 e capire quali trasformazioni abbiano subito questi centri campione negli ultimi venti anni sotto il profilo demografico (fig. I0).

Prima di iniziare, pertanto, è stato necessario delimitare il campo d'indagine utilizzando come criterio cardine il numero assoluto di residenti nei comuni. Secondo il rapporto di Confcommercio e Legambiente 1996/2016 Eccellenze e ghost town nell'Italia dei piccoli comuni [Polci, Gambassi 2008] un comune è considerato "sofferente", a rischio di disagio in-

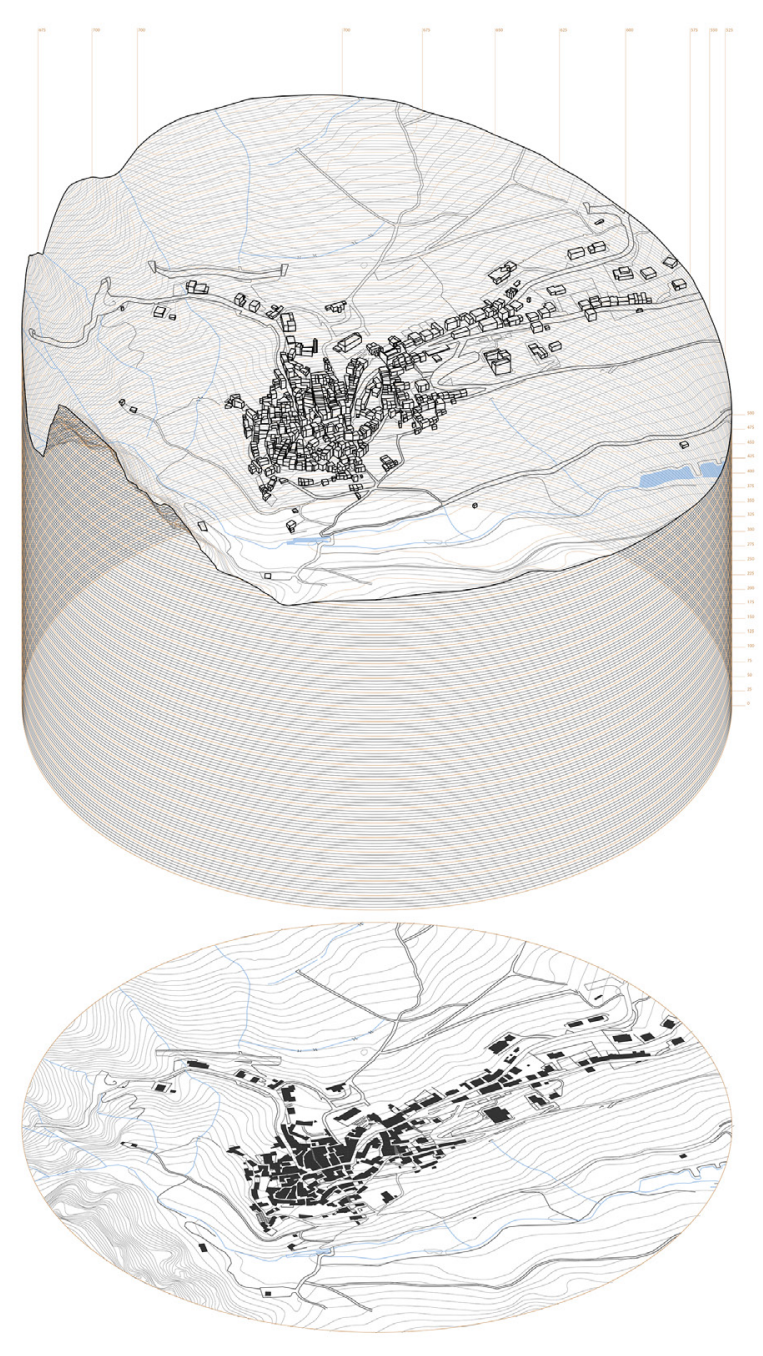


sediativo, quando scende al di sotto dei 5.000 abitanti (i cosiddetti Piccoli Comuni [La Nave, Testa 20 I5]), tuttavia questo dato per l'Abruzzo apre una casistica troppo ampia. Infatti, secondo i dati ISTAT riferiti al 2020, nella regione sono presenti ben 25 I comuni con queste caratteristiche a fronte di un totale di 305. In pratica l'82\% dei comuni abruzzesi è a rischio spopolamento. Andando a studiare ancora meglio i dati, di questi 25 I comuni, 196 hanno meno di 2000 abitanti - 64\% del totale - e ben 65 meno di 500 abitanti - 21\% del totale. $\grave{E}$ proprio su questi 65 comuni che si è concentrata l'indagine, poiché si tratta di centri oramai quasi disabitati in cui rischio di estinzione è particolarmente elevato.

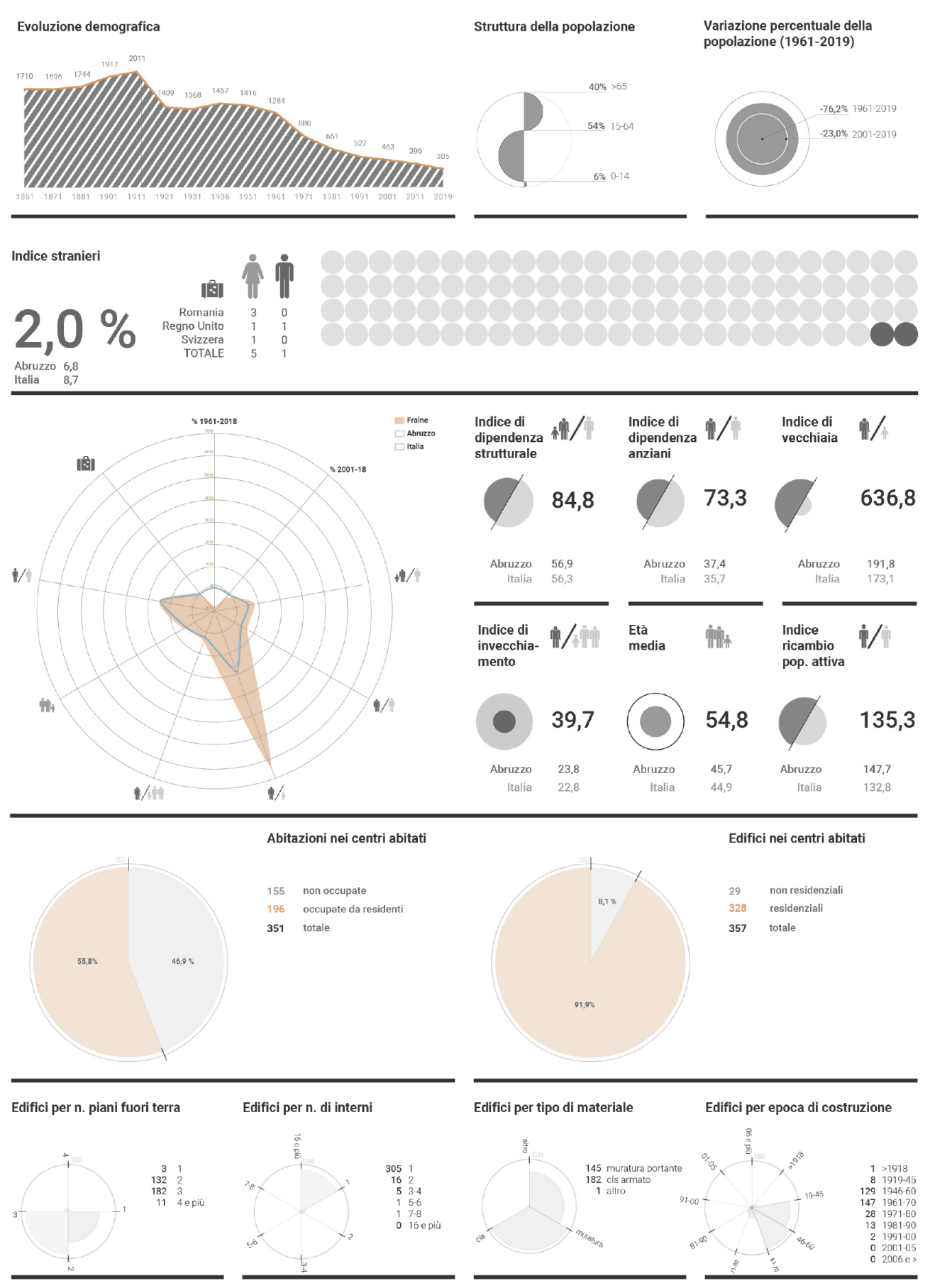

Evoluzione demografica 


\section{Fasi e azioni}

Una delle peculiarità dell'Atlante dei borghi solitari consiste nel suo voler essere un sistema dinamico che intreccia relazioni e confronti. Per la sua articolazione necessariamente complessa si possono evidenzire alcune delle azioni che sono servite a realizzare l'atlante. La prima azione è consistita nella ricerca e selezione dei materiali da studiare e rielaborare. La scelta dei materiali è avvenuta secondo i criteri di pertinenza, valore storico, artistico, architettonico e paesaggistico. Si è proceduto poi alla raccolta dei materiali di base cartografici consultabili in rete attraverso il geoportale della regione (geoportale.regione.abruzzo.it) o attraverso altre risorse disponibili. Un ulteriore passo di questa fase iniziale è consistito nella redazione di una bibliografia specifica per ogni comune analizzato. Una seconda fase ha riguardato il reperimento dei dati di tipo demografico e statistico attraverso il portale Istat (demo.istat.it/) e all'ultimo censimento effettuato nel 20II (dati-censimentopopolazione. istat.it). Una terza azione/fase ha visto la redazione di grafici ed elaborazioni tridimensionali a diverse scale che studino i borghi nella loro configurazione e distribuzione planimetrica, nel loro rapporto con il paesaggio, nel loro impianto planimetrico (a scala 1:5000) fino ad arrivare alla rappresentazione tridimensionale di una sorta di carotaggi del terreno in cui si coglie il rapporto tra abitato e orografia (fig. 9). La quarta azione/fase ha visto l'esplorazione diretta dei luoghi a cui si devono i disegni a mano (figg. I I, I2) e la realizzazione di una

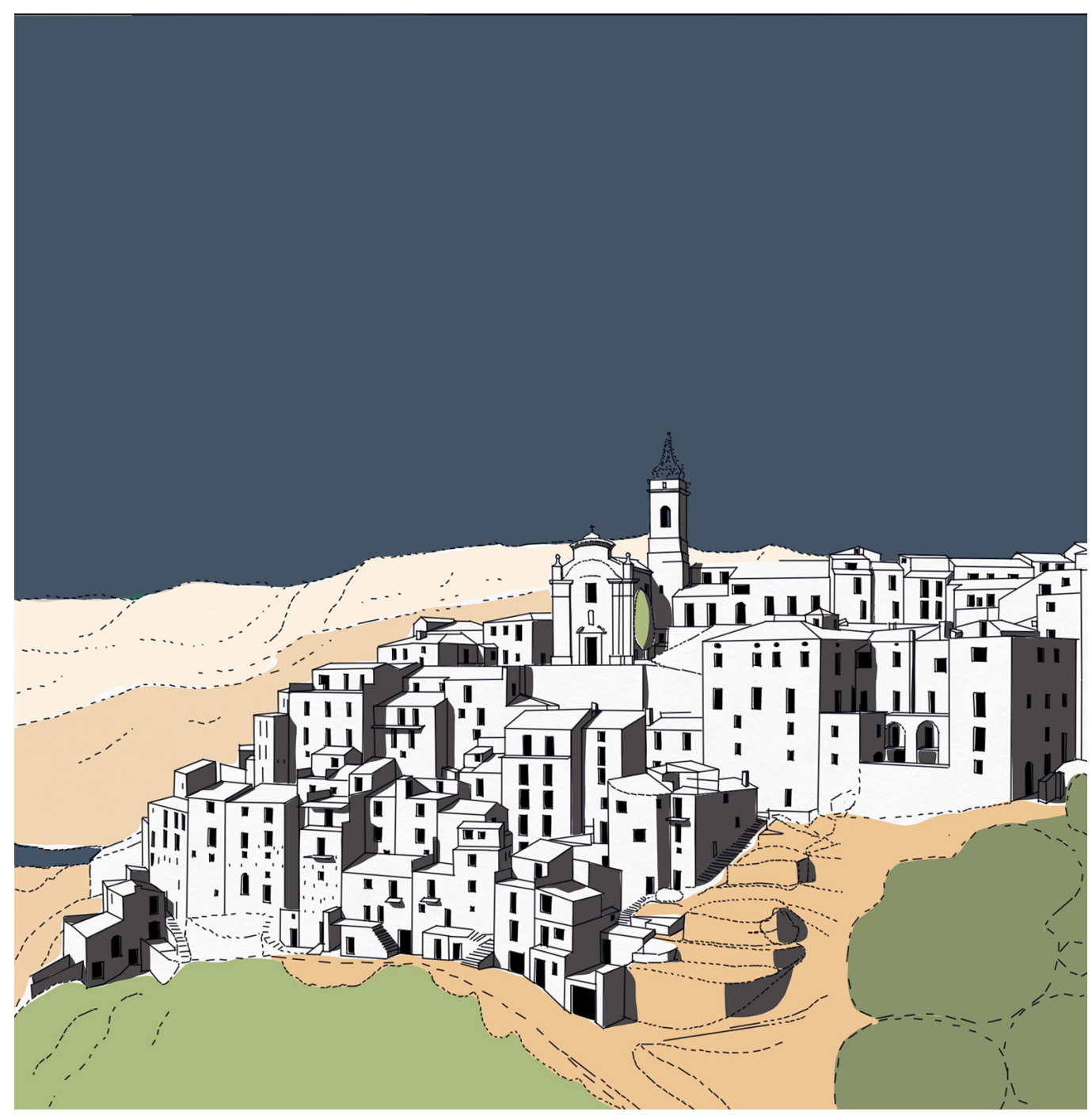


campagna fotografica del fotografo di architettura Giuseppe Marino. Lo scopo di questa campagna fotografica non è stato meramente documentario ma ha cercato di tradurre in immagini la vita e le azioni che quotidianamente conformano questi spazi (figg. I-3).

\section{Conclusioni}

In questo saggio si sono intrecciate due differenti indagini che rappresentano il cuore pulsante della ricerca generale. Da una parte il tema dello spopolamento dei "piccolissimi" centri abruzzesi e dall'altro la capacità del disegno di dar sostanza e voce a sistemi complessi attraverso strumenti flessibili in cui grafica architettonica, disegno a mano, modelli tridimensionali, diagrammi statistici e fotografia collaborano a formare combinazioni sinergiche. Del resto, non è un caso se oggi l'attenzione generale sia puntata sui piccoli centri grazie a tutta una serie di progetti: partendo dalla SNAI possiamo citare la decisione del Mibact di dedicare l'anno 2017 ai borghi d'Italia per sviluppare il patrimonio artistico, naturale e umano di luoghi; la cosiddetta Legge Salva Borghi, n. 254I del 27 settembre 2017, in cui è stato previsto un fondo da 100 milioni di euro fino al 2023 per attuare misure per il recupero dei centri storici in abbandono o a rischio spopolamento; per arrivare ai numerosi progetti censiti e documentati in Arcipelago Italia. Progetti per il futuro dei territori interni del Paese, tema del Padiglione italiano alla Biennale diVenezia [Cucinella 20 I 8]. La rappresentazione di questi borghi, e la successiva costruzione di un atlante ibrido, si inserisce in questo rinnovato interesse e propone un racconto dei luoghi che, a partire dalla condizione presente, faccia immaginare anche possibili futuri. Questa ricerca, in cui disegno, cartografia, statistica e infografica si incontrano, punta pertanto a evidenziare quelle energie in grado di trasformare situazioni di crisi in momenti di evoluzione. In questa logica, rappresentare l'esistente, che sia quello materico dell'architettura, quello empatico della comunità o quello astratto dei dati, è il primo, fondamentale, passo prima di qualsiasi attività. Ė a partire da questo triplice fuoco nella rappresentazione - il primo rivolto allo spazio fisico attraverso i disegni cartografici, il secondo di stampo antropologico e sociale, il terzo rivolto allo spazio fluido dei dati- che abbiamo cercato di tracciare un percorso che mette alla prova la potenza e versatilità del disegno.

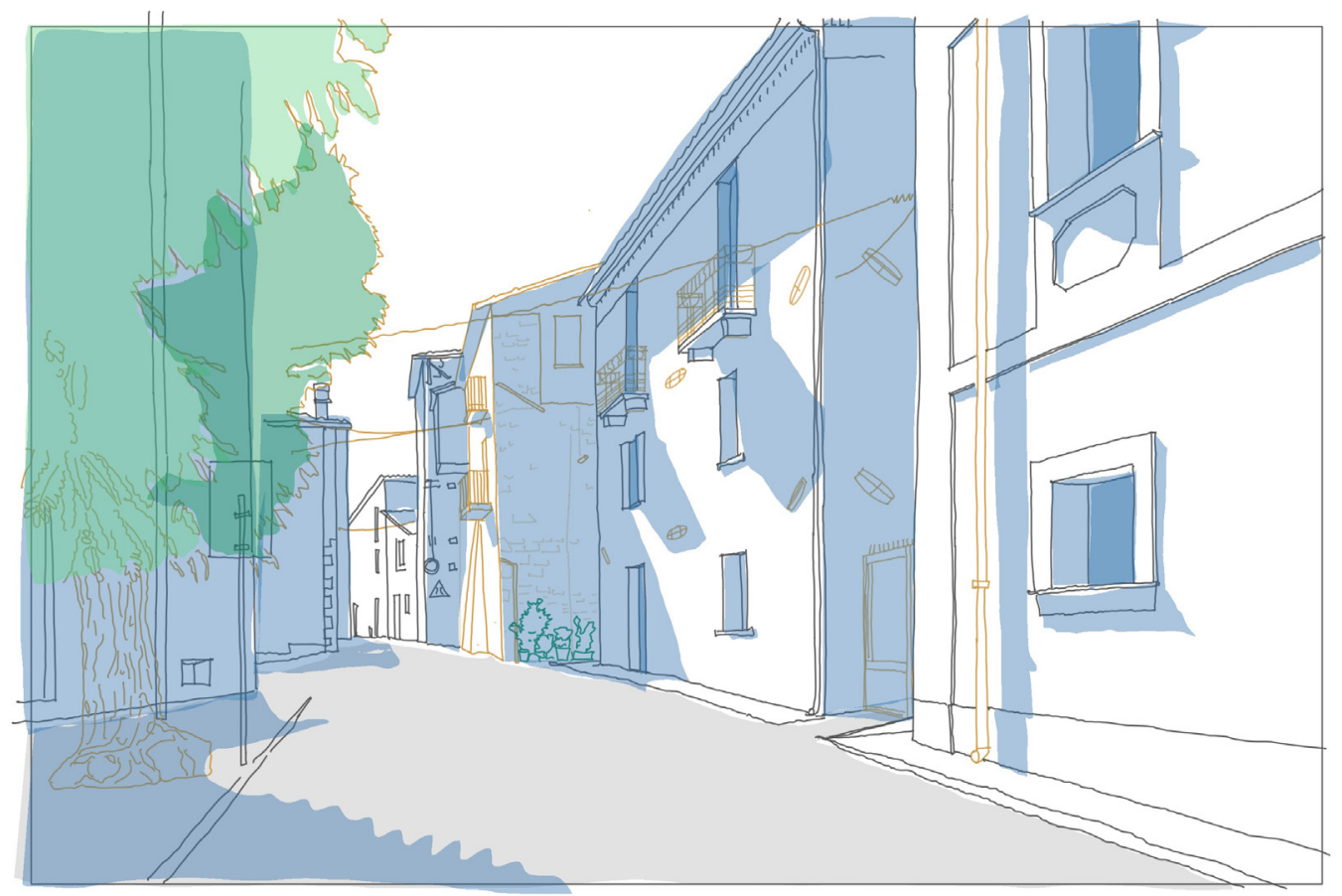




\section{Riferimenti bibliografici}

Caffio G. (20।8). Sperimentazioni di rilevamento per mappare architetture della memoria: i borghi d'Abruzzo. In R. Salerno (a cura di). Rappresentazione/Materiale/Immateriale. Drawing as (In)Tangible Representation. Atti del 40 Convegno Internazionale dei Docenti delle Discipline della Rappresentazione. Milano I3-I5 settembre 20 I8, pp. 353-360. Roma: Gangemi Editore.

Cucinella M. (20 I 8). Arcipelago Italia: progetti per il futuro dei territori interni del Paese. Catalogo del Padiglione Italia alla Biennale di architettura di Venezia 2018. Macerata: Quodlibet

Golini A., Mussino A. e Savioli M. (2000). Il malessere demografico in Italia: una ricerca sui comuni italiani. Bologna: II Mulino.

La Nave M., Testa P. (a cura di). (20 I5). Atlante dei Piccoli Comuni 20 I 5. IFEL Fondazione ANCl. Roma: ANCl.

Oteri A.M. (2019). Architetture in territori fragili. Criticità e nuove prospettive per la cura del patrimonio costruito. In ArcHistoR anno VI n. II, pp. I69-205

Polci S., Gambassi R. (2008). 1996/20 I 6 Eccellenze e ghost town nell'Italia dei piccoli comuni. Rapporto promosso da Confcommercio e Legambiente<https://www.confcommercio.it/documents/20 I26/566895/rapporto-integrale.pdf/e34a3 | 45-2f09-e509-04bb7a5 1930bdb68? version= I. I \&t=| 35826907 |000> (consultato il 27 febbraio 202 I).

Polci S., Gambassi R. (2016). Piccolo (e fuori dal) Comune. Cosa sta cambiando nell'Italia dei piccoli comuni. Dossier elaborato per conto di Legambiente, Unioncamere e Symbola. <https://www.legambiente.it/sites/default/files/docs/dossier_piccoli_e_fuori_dal_ comune_piccolicomuni20 I6.pdf> (consultato il 27 febbraio 202I)

Salucci A., Marino G. (2017). Photography and Video for a Representation of the Intangible Cultural Heritage of Abruzzo. In G. Amoruso (ed.). Putting Tradition into Practice: Heritage, Place and Design. Proceedings of 5th INTBAU International Annual Event Milano 5-6 luglio 2017, pp. 727-736. Cham: Springer.

Solitario (voce). (202I). In Vocabolario Treccani [online] <https://www.treccani.it/vocabolario/solitario/> (consultato il 27 febbraio 2021).

Strategia Nazionale 2014 - Strategia nazionale per le Aree interne: definizioni, obiettivi, strumenti e governance. In Materiali Uval. Documenti, n. 31

Tarpino A. (20I2). Spaesati: luoghi dell'Italia in abbandono tra memoria e futuro. Milano: Einaudi.

Tarpino A. (2016). Il paesaggio fragile: I'Italia vista dai margini. Milano: Einaudi.

Teti V. (2004). Il senso dei luoghi. Memoria e storia dei paesi abbandonati. Roma: Donzelli.

Teti V. (20 I7). Quel che resta. L'Italia dei paesi, tra abbandoni e ritorni. Roma: Donzelli.

Unali M. (2020).Verso un Atlante dei Beni Immateriali Abruzzesi. In L. Pignatti (a cura di). Territori fragili. Saggi ed approfondimenti dopo IFAU 2018, pp. 687-696. Roma: Gangemi.

\section{Autore}

Giovanni Caffio, Università "G. d'Annunzio", Chieti-Pescara, giovanni.caffio@unich.it

Per citare questo capitolo: Caffio Giovanni (2021). Atlante dei borghi solitari: il disegno per le micro-città d'Abruzzo/Atlas of lonely Towns: the drawing for Abruzzo's micro-cities. In Arena A., Arena M., Mediati D., Raffa P. (a cura di). Connettere. Un disegno per annodare e tessere. Linguagg Distanze Tecnologie. Atti del $42^{\circ}$ Convegno Internazionale dei Docenti delle Discipline della Rappresentazione/Connecting. Drawing for weaving relationship. Languages Distances Technologies. Proceedings of the $42^{\text {th }}$ International Conference of Representation Disciplines Teachers. Milano: Franco Angeli, 26I-284. 


\title{
Atlas of Lonely Towns: the Drawing for Abruzzo's Micro-Cities
}

\author{
Giovanni Caffio
}

\section{Abstract}

The representation project presented in this paper, the Atlas of Lonely Towns, proposes a path of architectural, urban and territorial mapping, as a starting point for multidisciplinary processes of knowledge, an essential act to be able to imagine and plan future economic, environmental and social developments. The representation project is carried out through actions of drawing and re-drawing, at different scales, of micro-cities in Abruzzo at risk of depopulation in order to increase awareness and shared knowledge of these often forgotten spaces. The work of multi-scalar mapping can thus testify to the architectural, urban and economic transformations of a territory that, like the communities that live in it, is in a slow but constant state of transformation. Moreover, the study shows how the contents and the elaborations present in the Atlas have the ambitious goal of constituting a flexible platform able to accommodate new and multiple information and to trigger processes of participation and enhancement for communities and local administrations.

\section{Keywords}

Representation, small towns, territory, depopulation, Abruzzo.

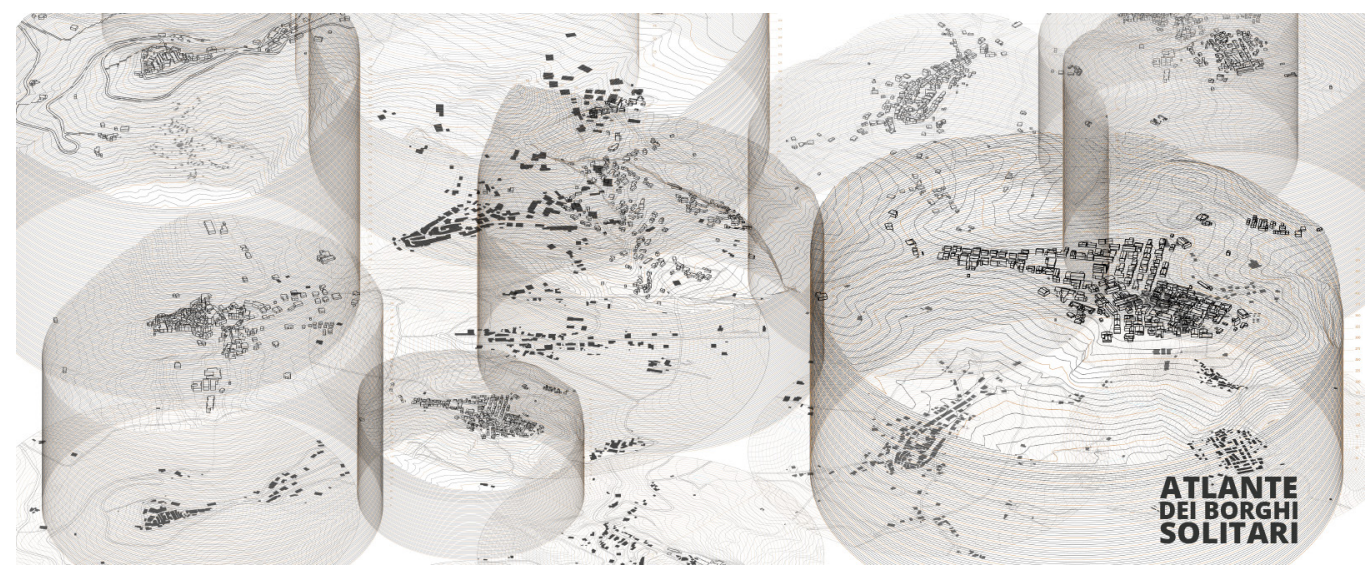




\section{Introduction}

For several years within the Department of Architecture of Pescara some professors of the area of Representation have been engaged in studying the small villages of Abruzzo through works of mapping, surveying, photographing and drawing of a rich tangible and intangible heritage that, due to the dynamics of depopulation, risks being forgotten and therefore lost [Caffio 20 I8; Salucci, Marino 20 I7; Unali 2020]. The territory of Abruzzo, as well as in general the Italian territory related to the Alpine arc and the Apennine ridge, is characterized by the presence of countless small towns. These centers, once the backbone of the local economy and now a fading trace of past history, have been losing substantial parts of their population for decades at a slow and seemingly unstoppable pace. At the origin of this depopulation there are many endogenous and exogenous causes: environmental catastrophes that have occurred over time, socio-economic paradigm changes, new territorial structures caused by infrastructure and production facilities. According to several scholars [Golini et al. 2000], depopulation, especially in large areas of the foothills, mountains and islands, has now assumed a structural nature, characterizing large areas in which the problem of settlement distress is only one effect of heterogeneous and synergistic causes. Described and analyzed in its many implications by scholars such as Vito Teti [20 I7; 2004] and Antonella Tarpino [Tarpino20I6; Tarpino 20I 2], this process of disappearance of historical centers has caused, as a further consequence, the transformation of much of the physiognomy of the adjoining territories: cancellation of the forms of living but also mutation of the neighboring landscape. This condition in the areas of smaller centers is then exacerbated by the absence of state economic policies aimed at encouraging new and more modern material and immaterial infrastructure. In this way, small centers have, in fact, lost the possibility of survival and, in cases where they have not yet been completely abandoned, continue to exist thanks to a kind of stubborn resistance [Polci, Gambassi 20 I6] (figs. I, 2).
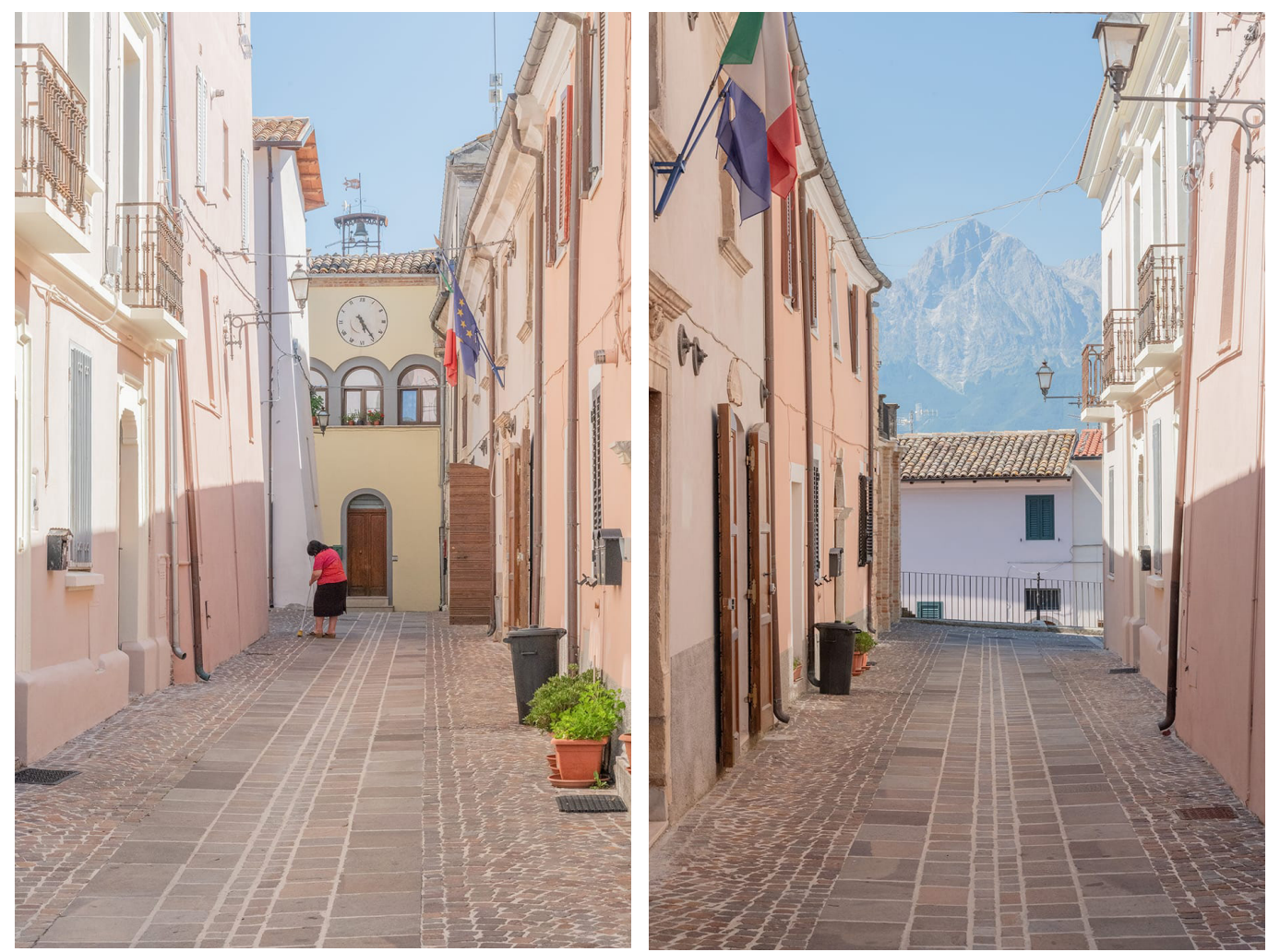


\section{Internal, fragile, marginal... lonely}

To counteract this decline, in 2014 the Italian government prepared the ambitious plan of the National Strategy of Inland Areas [SNAI 20I4], a plan elaborated within the broader territorial cohesion programs that overturns the approach based on industrial development and the predominance of large metropolises by placing again at the center of the political agenda the territories considered marginal. It is interesting to note how in the SNAI the internal areas are identified and classified according to their 'distance' from primary services such as education, health and mobility, therefore their being 'internal' is not in reference to the geographical and territorial body but to their being distanced from the possibility of accessing the civil rights contemplated by our Constitution. In the case of this atlas, instead of using the adjectives 'internal', 'small','fragile', 'marginal','neglected' that are often associated with these villages in the press, we have preferred the less obvious and predictable 'lonely'. The adjective 'lonely' was chosen because of its multiple meanings:

a. One who is alone, and especially one who loves to be alone, who avoids the company of one's fellows.

b. Who is alone, secluded, far from others; isolated.

c. Of places, deserted, 'unfrequented'.

But also:

"Brilliant of considerable merit, both in size and in cut and light, set alone, with a very light binding that leaves it as uncovered to view as possible, in a ring" [Solitaire 202 I].

The idea of this atlas, therefore, is to overturn the negative preconceptions that form the aura of these centers by transforming their peculiarities into positivity. An attitude of enhancement and care of the potentials present in these places starting from their being small, and therefore more manageable; far away, and therefore more protected from the unpredictable dynamics of today's society - see pandemic-; old, and therefore more resilient; sparsely inhabited, and therefore silent and peaceful as well as closer to nature and the landscape of which they are an integral part (fig. 3).

Fig. 3. Rocca di Cambio (480 inh.) in the province of L'Aquila (photo by Giuseppe Marino).

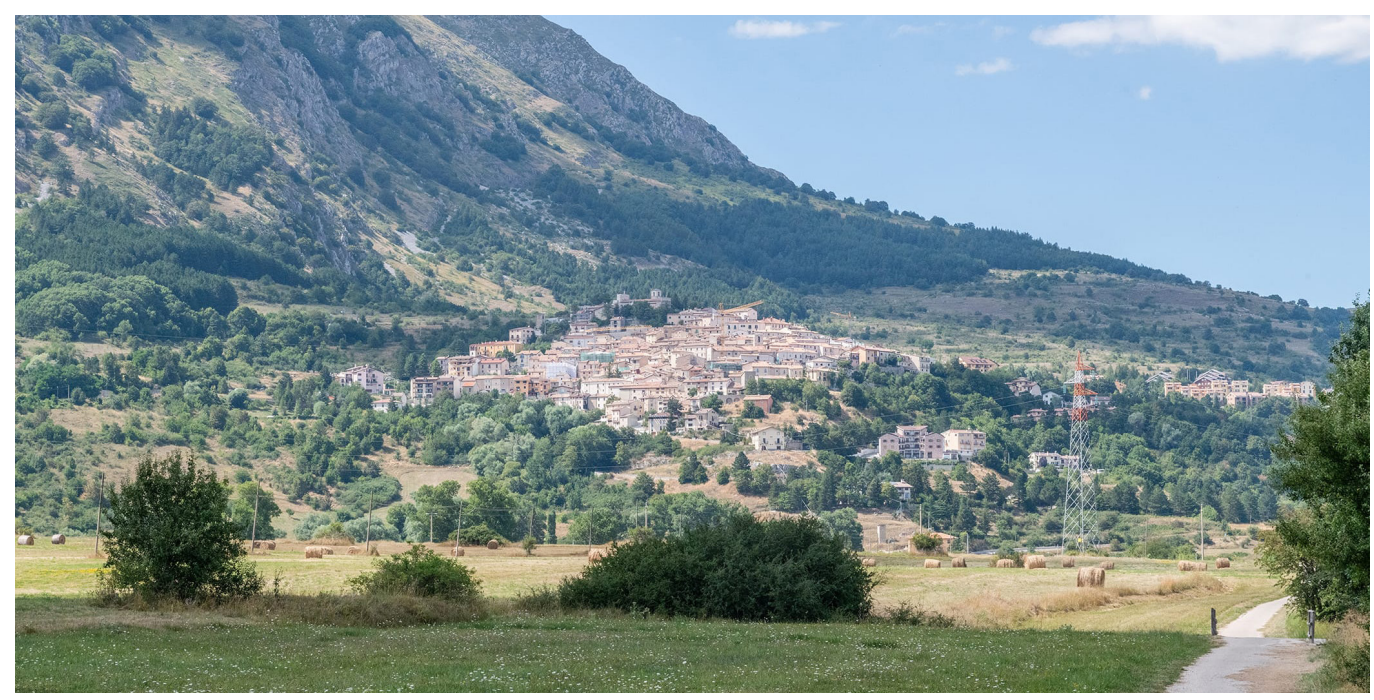

\section{An ambitious goal}

As the title of the research suggests, the Atlas of Lonely Towns is first and foremost a project of research and representation of places and spaces of living in constant, albeit slow, transformation. Therefore, its first goal is to study and bring out the potential of abandoned places and to trigger a prolific dialogue between them and the creative energies of the atlas' visitors or scholars (fig. 4). By showing the architectures and the built spaces, and their cul- 
tural and social values of which they are a testimony and a material trace, the atlas intends to encourage a possible new relationship between past and future life, promoting new temporary uses and transformation processes that escape the exclusive perspective of tourist exploitation towards less obvious and superficial options as they are linked to the history and culture of local communities.

As Annunziata Maria Oteri writes, "As for fragile people, who do not need prodigious drugs but need to be listened to, an important role can therefore be played by communities, understood in a therapeutic key of 'community of care' or, even of 'community of destiny', that is, citing Borgna again, of 'forms of life, of human closeness and solidarity' in which 'the strongest gives a hand to the weakest'" [Oteri 2019, p. 189]. In this sense, the Atlas project stands as a point of listening, a place where local communities can find expression of their being, with all the idiosyncrasies that this entails in being distant if not removed from the current discourse; a space for comparison and growth in which to be recognized and respected without incurring in salvific, paternalistic or, at worst, predatory attitudes.

The main purpose of this atlas is, in fact, to bring attention to these centers through experimentation with processes of adaptive representation, in which the adjective is employed to emphasize the different meanings of this vision. First of all there is the idea of a representation that adapts to the scale and the context without ever expiring in the picturesque or postcard effect that often frames the representations of the villages in the mainstream; secondly it refers to the fact that it applies to living organisms that are constantly changing

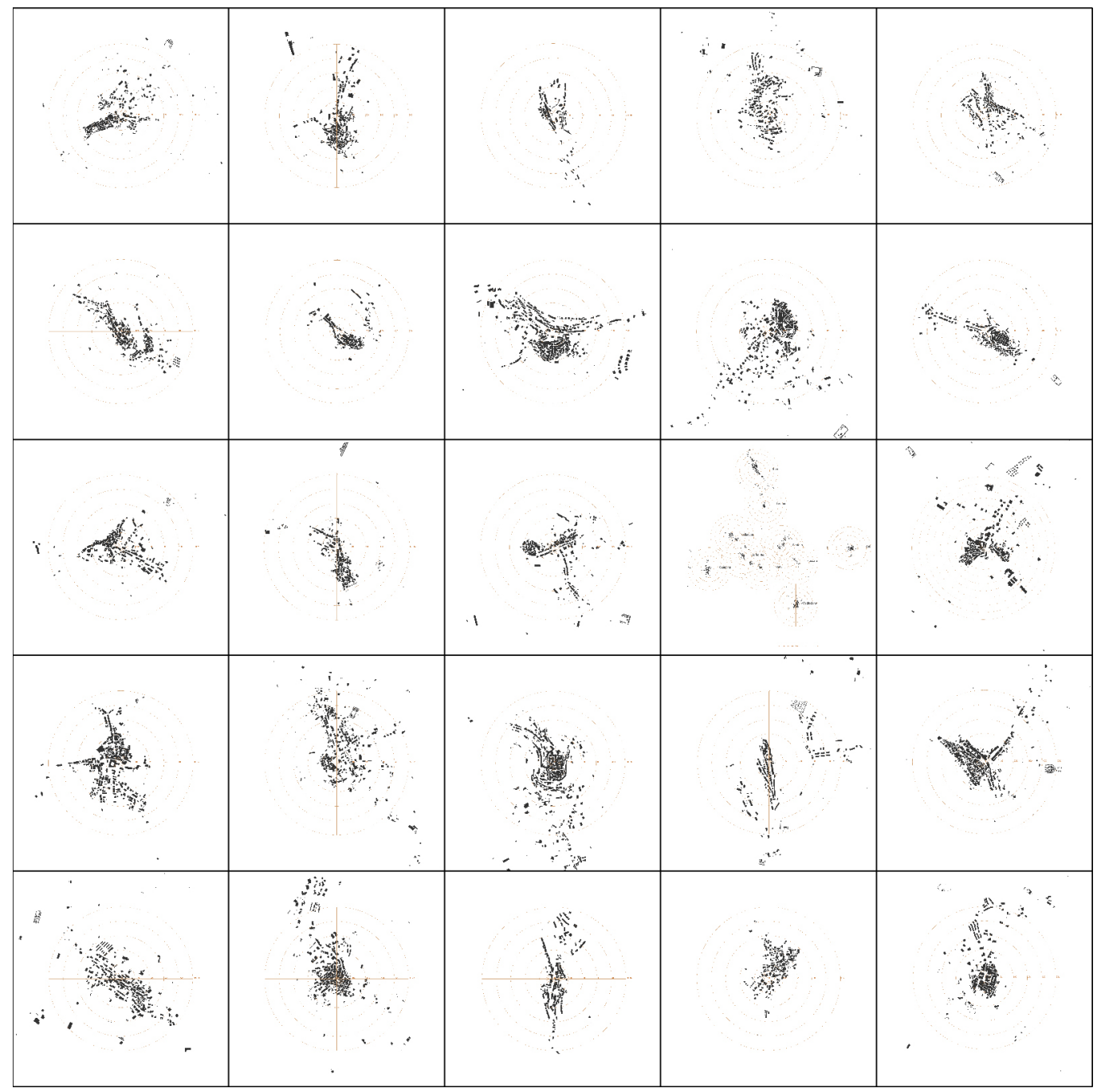


and therefore the design must highlight hard elements around which soft elements related to more dynamic and evolving activities turn; finally, the representation must be able to take into account the temporal component experimenting with different degrees of change or dynamism declaring that these are drawings always in progress and never definitive.

In the representation, in fact, the design of the architectural heritage and the environment is a platform for an integrated vision in which the physical representation of architectural volumes meets that relating to social processes through statistical and demographic surveys that can combine even graphically the knowledge and interpretation of the physical urban heritage with that of the demographic dynamics of the population that inhabits and uses it. A common denominator of these hybrid forms of representation is the desire to seek new combinations that favor the construction of a new shared narrative on the quality of these territories.

This narrative, which today we associate with the term storytelling borrowing it from other linguistic areas, must start from the recognition of the set of resources of the territory, often unknown to the same community, not as a simple act of identity but as the core of an evolutionary process and growth. The drawing, therefore, aims to operate an organization of the multiple information that is obtained from the places through the identification of elements with a strong symbolic charge -monuments, specific places, historical buildings, spaces of aggregation- that can act as reference points in the processes of change, a sort
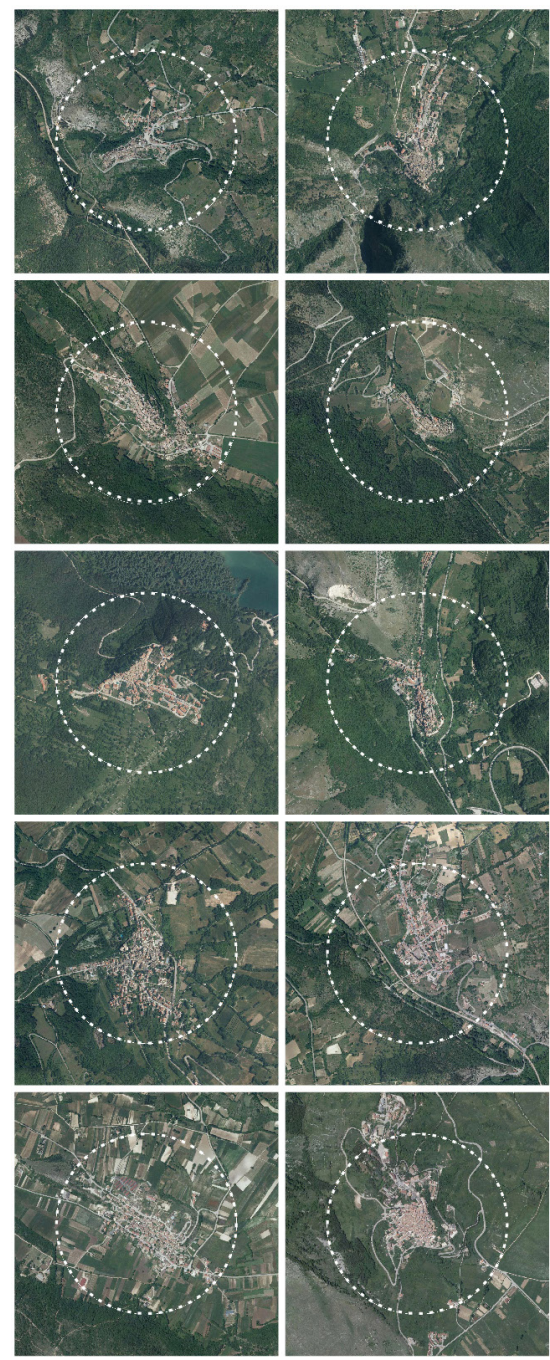
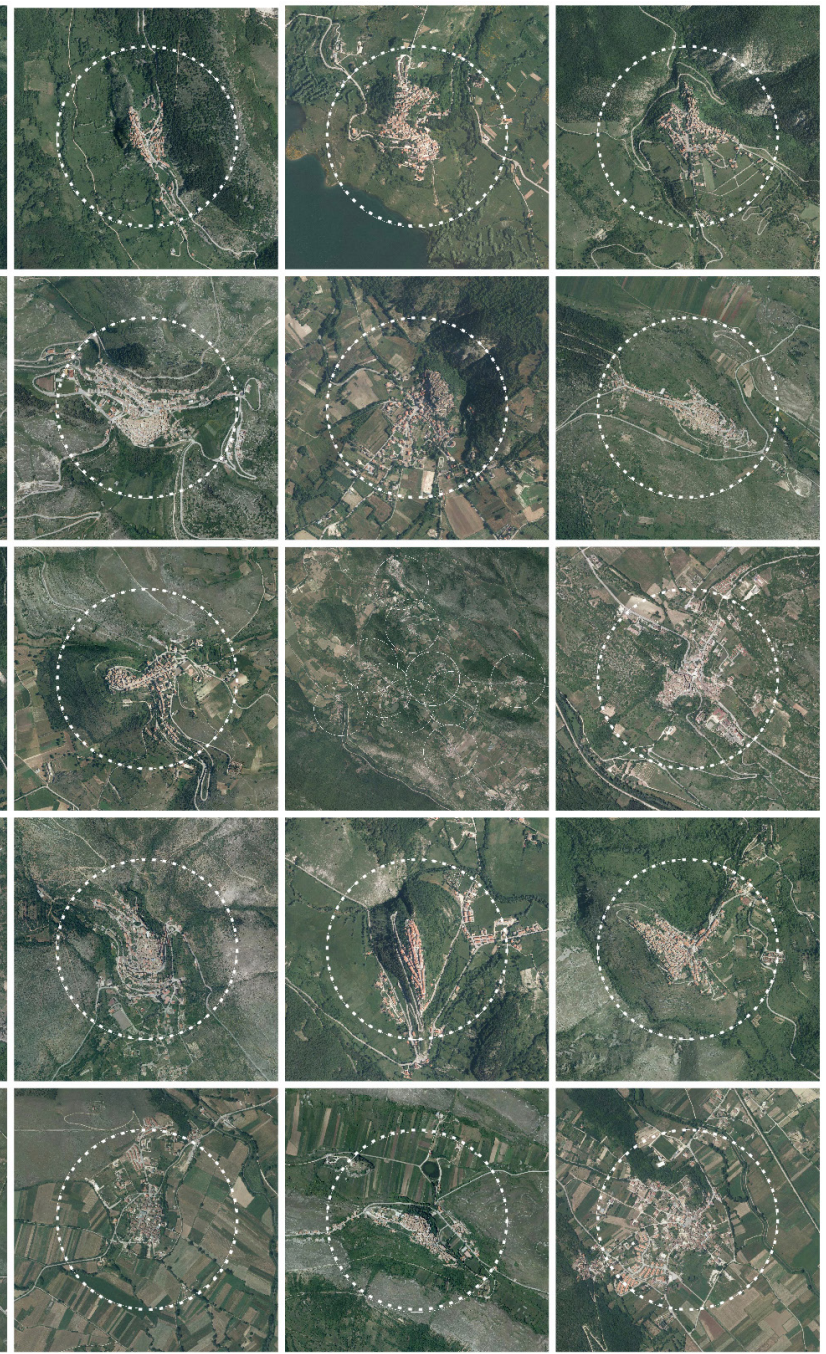
of "safety devices" [Oteri 2019, p. 191] around which to regroup and actualize knowledge and cultures of the past. By seeking the integration of different representations (floor plans, three-dimensional models, diagrams and statistical graphs, photography and hand drawing) and experimenting with possible synergistic approaches, this atlas aims to elaborate descriptions of places that are effective, evocative, flexible and useful (figs. 6-8).

After so much attention has been given to forms of survey based on instruments and methods that, though undoubtedly effective and irreplaceable, increasingly distance the observer from the object to be represented (concrete and heavy objects that dematerialize into clouds of points, walls whose complex stratigraphy tells of materials and techniques sedimented in the territory transformed into mesh surfaces; aerial views of flying drones that render concrete spaces like film sets), this set of graphic and visual representations (fig. 9) aims to demonstrate that the objectives of an atlas can also be achieved through hybrid solutions that not only include recent technologies but also recover the designer's innate ability to apply his or her sensitivity to the knowledge and interpretation of space through the tools of drawing (starting with freehand drawing and the rational and conscious use of lines) and returning to occupy physical space by interacting with its inhabitants. A designer who does not limit himself to looking down on the village or to capturing the most visually appealing and 'sellable' aspects, but who becomes the representative of a direct attention, a participant in the future and in the care of the places. Our idea, therefore, is that of a drawing as an instrument of 'listening' to fragile territories, a form of pact/connection between
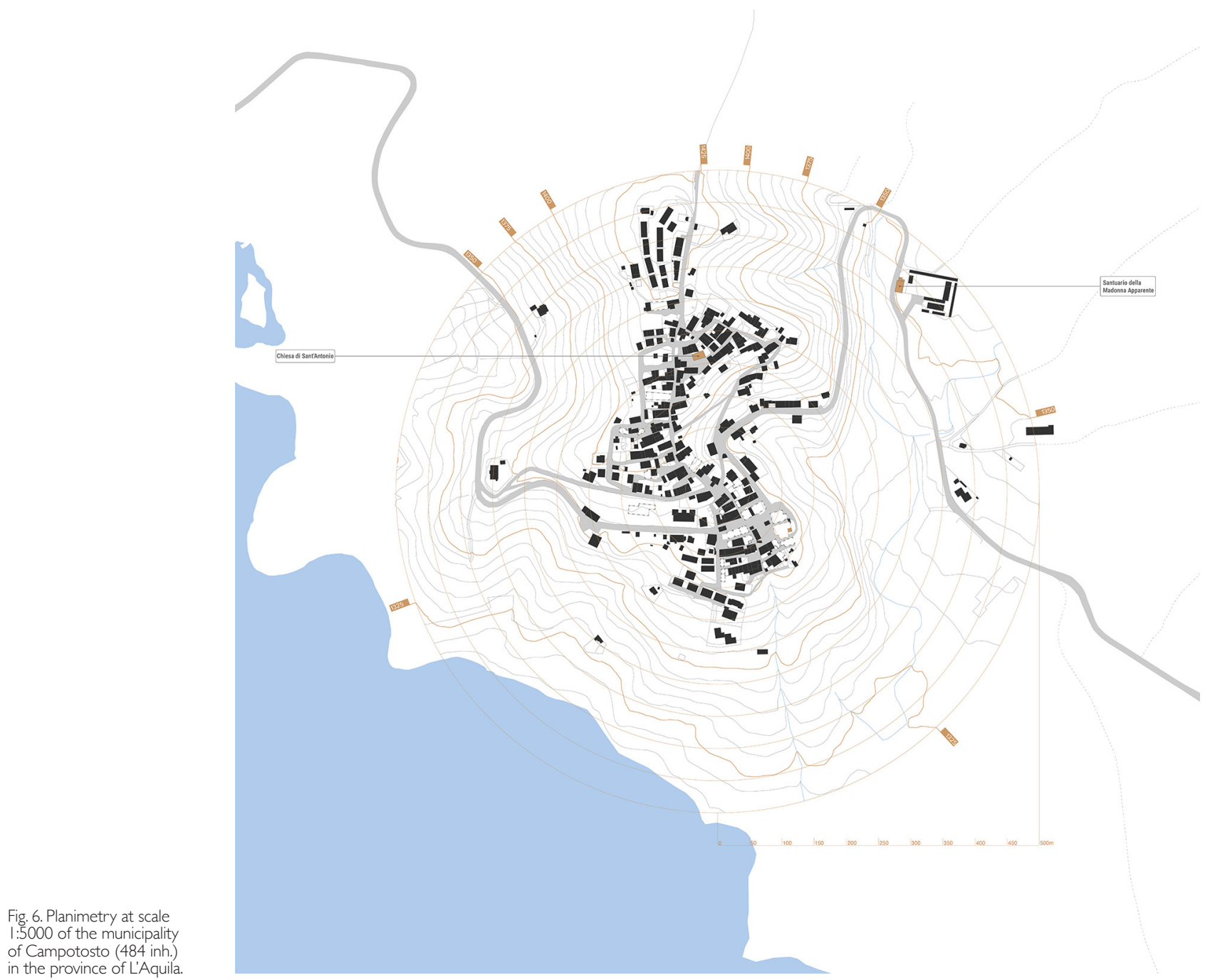
those who come from outside and those who have remained in these almost abandoned villages. At the base of the project of this atlas there is a form of ethical and civic commitment that can be a catalyst for new opportunities for study and development: from projects of preservation of architectural and cultural heritage to processes of sustainable urban regeneration; from a transformation of uses and properties to design tools that establish new relationships between architecture, spaces and uses of the resident communities.
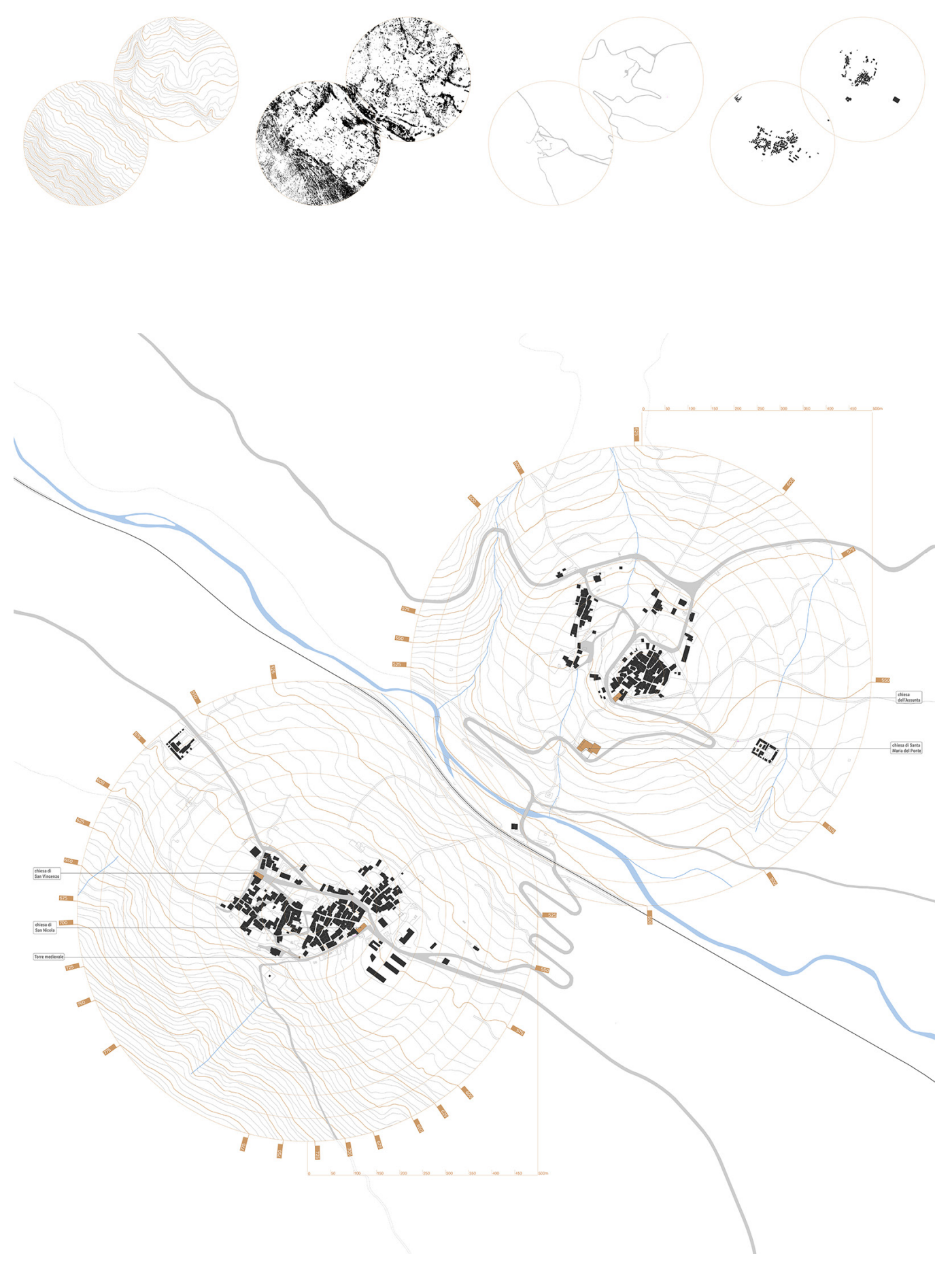


\section{The perimeter of research}

The drawings presented here were an opportunity to investigate the semantic code and the process of translation that information can undergo through representation. The developed graphics are the result of an exploration of the ways in which drawing can take on a new role in relation to the different types of data (geographic, architectural, and demographic) available to us, allowing us to understand, and then act upon, the intelligible space of information. Regardless of the technological tools used -modeling software, real-time visualizations of datasets, or simply paper and pencil- this research aims to explore one of the fundamental functions of drawing, namely, to communicate in a simple and direct manner while always declaring its being a medium and not a simulacrum. In approaching this research, we have moved trying to pursue two aims, namely to elaborate a description of the state of affairs of the very small villages of Abruzzo updated to 2020 and to understand what transformations these sample centers have undergone in the last twenty years from a demographic point of view (fig. 10).

Before beginning, therefore, it was necessary to delimit the field of investigation using as a pivotal criterion the absolute number of residents in the municipalities. According to the report of Confcommercio and Legambiente 1996/2016 Eccellenze e ghost town nell'Italia dei piccoli comuni [Polci, Gambassi 2008] a municipality is considered "suffering", at risk of

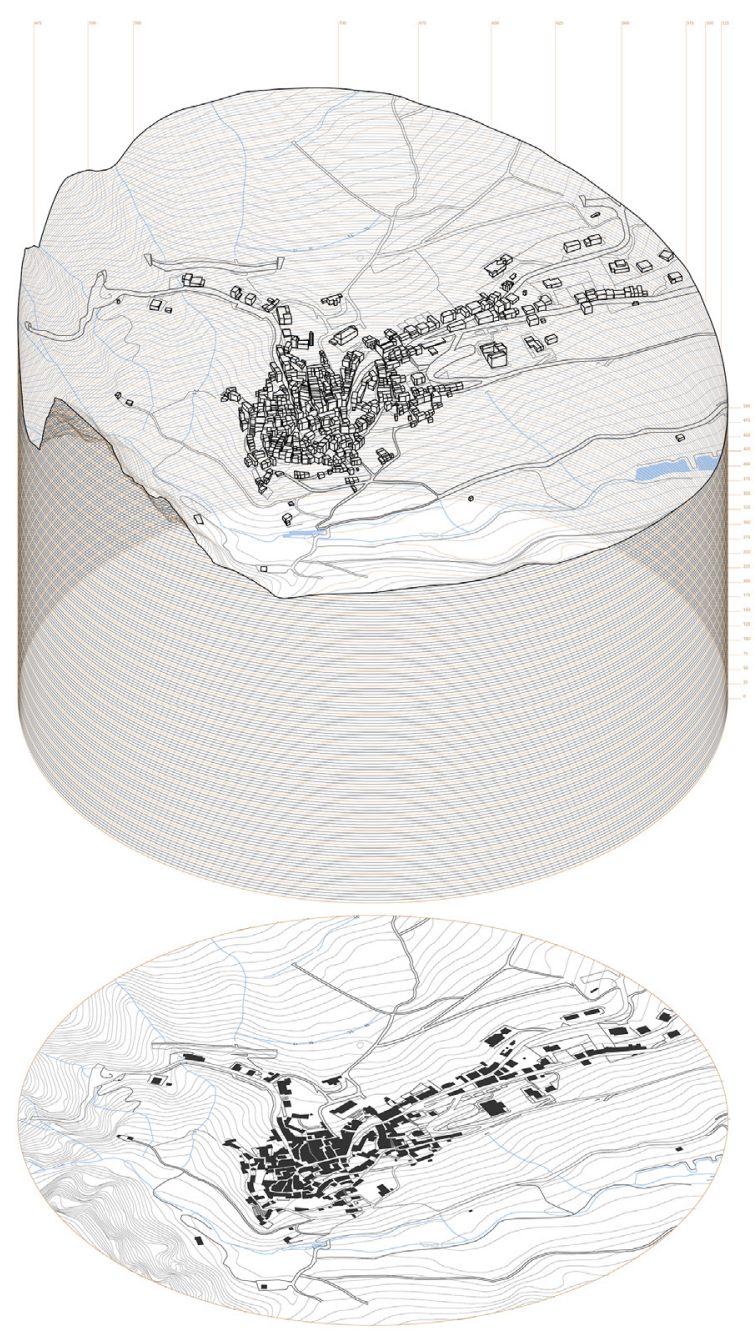


settlement discomfort, when it falls below 5,000 inhabitants (the so-called Piccoli Comuni [La Nave, Testa 20 I5]), however, this figure for Abruzzo opens a case study too wide. In fact, according to ISTAT data referring to 2020, in the region there are as many as 25 I municipalities with these characteristics compared to a total of 305. In practice, $82 \%$ of Abruzzo municipalities are at risk of depopulation. Studying the data even more closely, of these 251 municipalities, 196 have fewer than 2000 inhabitants - 64\% of the total -and 65 have fewer than 500 inhabitants- $21 \%$ of the total. The survey focused on these 65 municipalities, as they are almost uninhabited centers where the risk of extinction is particularly high.

Evoluzione demografica

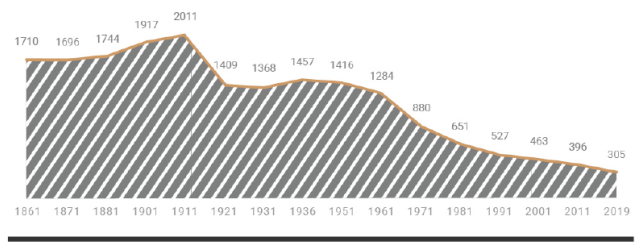

Indice stranieri
Struttura della popolazione

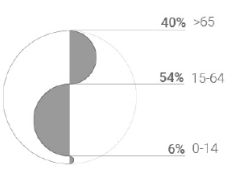

Variazione percentuale della popolazione (1961-2019)

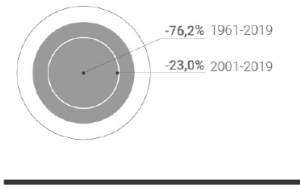

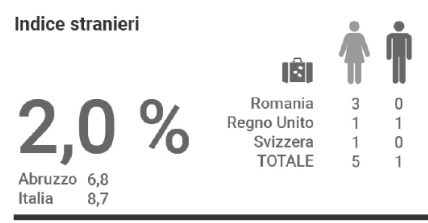

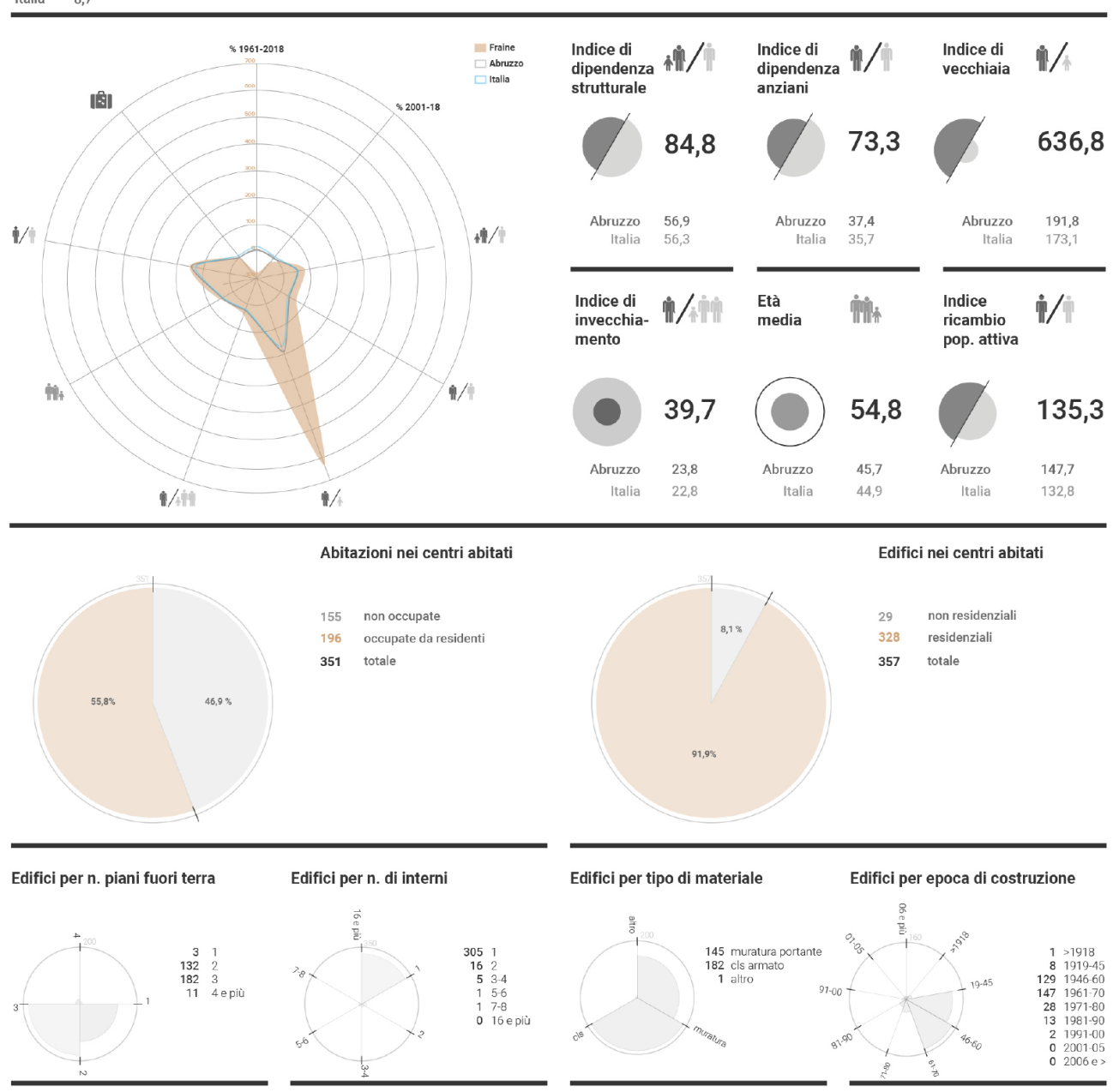

Fig. 10. Municipality of Fraine (292 inh.) in the province of Chiet Statistical diagrams regarding the main demographic indicators and characteristics of the inhabited area. 


\section{Steps and actions}

One of the peculiarities of the Atlas of Lonely Villages consists in its desire to be a dynamic system that interweaves relationships and comparisons. Because of its necessarily complex articulation, it is possible to highlight some of the actions that have served to realize the atlas. The first action consisted in the research and selection of materials to study and rework. The choice of materials was made according to the criteria of relevance, historical, artistic, architectural and landscape value. We then proceeded to the collection of basic cartographic materials available online through the geoportal of the region (geoportale.regione. abruzzo.it) or through other available resources. A further step in this initial phase consisted in drawing up a specific bibliography for each municipality analyzed. A second phase involved the retrieval of demographic and statistical data through the Istat portal (demo.istat.it/) and the last census carried out in 201 I (dati-censimentopopopolazione.istat.it). A third action/ phase has seen the drafting of graphs and three-dimensional elaborations at different scales that study the villages in their configuration and planimetric distribution, in their relationship with the landscape, in their planimetric layout (at 1:5000 scale) up to the three-dimensional representation of a sort of coring of the ground in which the relationship between built-up area and orography is captured. The fourth action/phase saw the direct exploration of the places to which the hand drawings are due (figs. II, I2) and the realization of a photo-

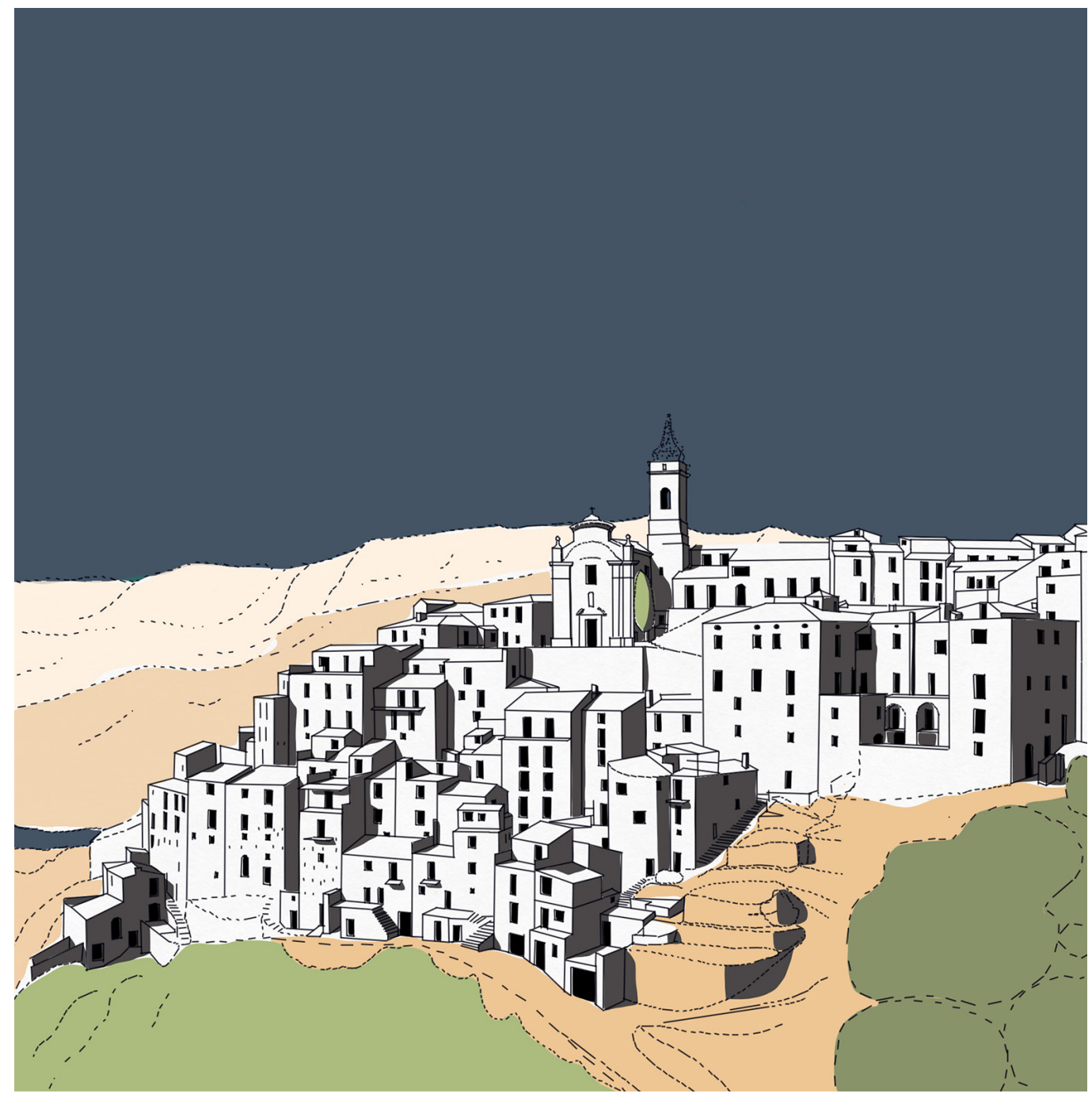


graphic campaign by the architectural photographer Giuseppe Marino. The purpose of this photographic campaign was not merely documentary but sought to translate into images the life and actions that daily conform these spaces (figs. I-3).

\section{Conclusions}

In this essay two different investigations have been intertwined, representing the beating heart of the general research. On the one hand, the theme of the depopulation of the 'very small' towns of Abruzzo and, on the other, the ability of drawing to give substance and voice to complex systems through flexible tools in which architectural graphics, hand drawing, three-dimensional models, statistical diagrams and photography work together to form synergic combinations. Moreover, it is no coincidence that today the general attention is focused on small towns thanks to a whole series of projects: starting from SNAI we can mention the decision of Mibact to dedicate the year 2017 to the villages of Italy to develop the artistic, natural and human heritage of places; the so-called "Legge Salva Borghi", no. 254I of September 27, 2017, in which a 100 million euro fund was provided until 2023 to implement measures for the recovery of historic centers in abandonment or at risk of depopulation; to get to the numerous projects surveyed and documented in Arcipelago Italia. Projects for the future of the country's internal territories, the theme of the Italian Pavilion at the Venice Biennale [Cucinella 20 I 8]. The representation of these towns, and the subsequent construction of a hybrid atlas, is part of this renewed interest and proposes an account of the places that, starting from the present condition, also makes us imagine possible futures. This research, in which drawing, cartography, statistics and infographics meet, aims therefore to highlight those energies able to transform situations of crisis into moments of evolution. In this logic, representing the existing, whether it is the material one of architecture, the empathic one of the community or the abstract one of data, is the first, fundamental step before any activity. It is starting from this triple focus in representation -the first one addressed to the physical space through cartographic drawings, the second one of anthropological and social nature, the third one addressed to the fluid space of data- that we tried to trace a path that tests the power and versatility of drawing.

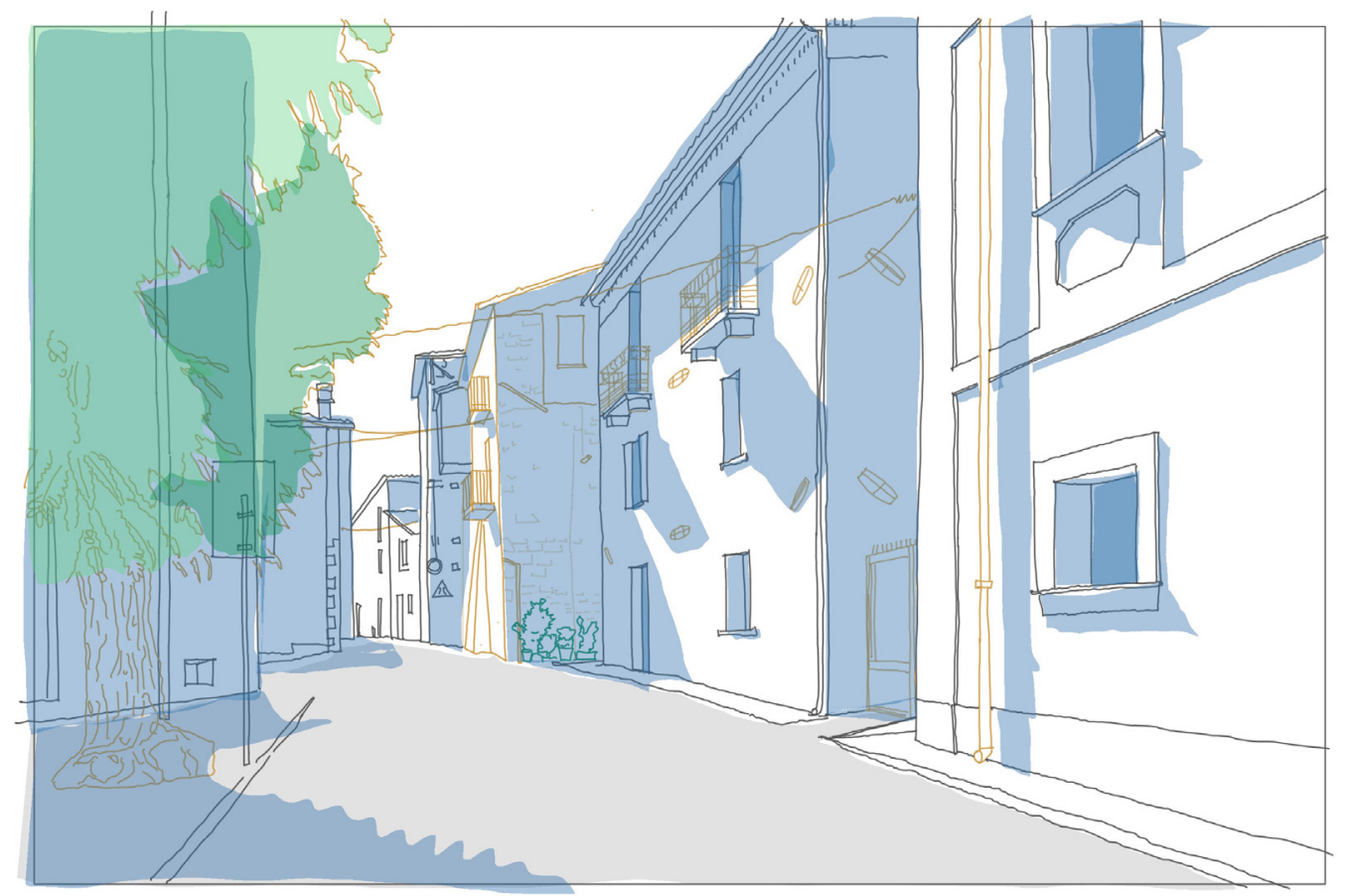




\section{References}

Caffio G. (20 I 8). Sperimentazioni di rilevamento per mappare architetture della memoria: i borghi d'Abruzzo. In R. Salerno (a cura di). Rappresentazione/Materiale/Immateriale. Drawing as (In)Tangible Representation. Atti del $40^{\circ}$ Convegno Internazionale de Docenti delle Discipline della Rappresentazione. Milano I3- 5 settembre 20 I8, pp. 353-360. Roma: Gangemi Editore.

Cucinella M. (20 I 8). Arcipelago Italia: progetti per il futuro dei territori interni del Paese. Catalogo del Padiglione Italia alla Biennale di architettura di Venezia 20/8. Macerata: Quodlibet.

Golini A., Mussino A. e Savioli M. (2000). II malessere demografico in Italia: una ricerca sui comuni italiani. Bologna: II Mulino.

La Nave M., Testa P. (a cura di). (20 I5). Atlante dei Piccoli Comuni 20 I 5. IFEL Fondazione ANCl. Roma: ANCl.

Oteri A.M. (2019). Architetture in territori fragili. Criticità e nuove prospettive per la cura del patrimonio costruito. In ArcHistoR anno VI n. II, pp. I69-205

Polci S., Gambassi R. (2008). 1996/201 6 Eccellenze e ghost town nell'Italia dei piccoli comuni. Rapporto promosso da Confcommercio e Legambiente<https://www.confcommercio.it/documents/20 I26/566895/rapporto-integrale.pdf/e34a3 | 45-2f09-e509-04bb7a5 | 930bdb68? version= | | \&t=| 35826907| 000> (accessed 202| February 27).

Polci S., Gambassi R. (20 I6). Piccolo (e fuori dal) Comune. Cosa sta cambiando nell'Italia dei piccoli comuni. Dossier elaborato per conto di Legambiente, Unioncamere e Symbola. <https://www.legambiente.it/sites/default/files/docs/dossier_piccoli_e_fuori_dal_ comune_piccolicomuni2016.pdf> (accessed 202I February 27)

Salucci A., Marino G. (2017). Photography and Video for a Representation of the Intangible Cultural Heritage of Abruzzo. In G. Amoruso (ed.). Putting Tradition into Practice: Heritage, Place and Design. Proceedings of 5 th INTBAU International Annual Event. Milano 5-6 luglio 2017, pp. 727-736. Cham: Springer

Solitario (voce). (202I). In Vocabolario Treccani [online] <https://www.treccani.it/vocabolario/solitario/> (accessed 202I, February 27).

Strategia Nazionale 2014 - Strategia nazionale per le Aree interne: definizioni, obiettivi, strumenti e governance. In Materiali Uval. Documenti, n. 31 .

Tarpino A. (2012). Spaesati: luoghi dell'Italia in abbandono tra memoria e futuro. Milano: Einaudi.

Tarpino A. (2016). Il paesaggio fragile: I'Italia vista dai margini. Milano: Einaudi.

Teti V. (2004). Il senso dei luoghi. Memoria e storia dei paesi abbandonati. Roma: Donzelli.

Teti V. (20 I7). Quel che resta. L'Italia dei paesi, tra abbandoni e ritorni. Roma: Donzelli.

Unali M. (2020).Verso un Atlante dei Beni Immateriali Abruzzesi. In L. Pignatti (a cura di). Territori fragili. Saggi ed approfondimenti dopo IFAU 2018, pp. 687-696. Roma: Gangemi.

\section{Author}

Giovanni Caffıo, Università “G. d'Annunzio”, Chieti-Pescara, giovanni.caffio@unich.it

To cite this chapter. Caffio Giovanni (202I). Atlante dei borghi solitari: il disegno per le micro-città d'Abruzzo/Atlas of lonely Towns: the drawing for Abruzzo's micro-cities. In Arena A., Arena M., Mediati D., Raffa P. (a cura di). Connettere. Un disegno per annodare e tessere. Linguaggi Distanze Tecnologie. Atti del $42^{\circ}$ Convegno Internazionale dei Docenti delle Discipline della Rappresentazione/Connecting. Drawing for weaving relationship. Languages Distances Technologies. Proceedings of the $42^{\text {th }}$ International Conference of Representation Disciplines Teachers. Milano: FrancoAngeli, pp. 26I-284. 